INTERNATIONAL

FOOD POLICY

RESEARCH

INSTITUTE

IFPRI

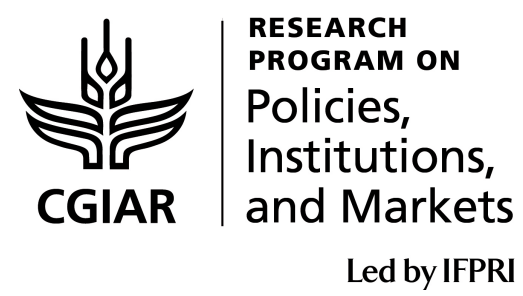

IFPRI Discussion Paper 01879

October 2019

Transfers, Nutrition Programming, and Economic Well-being

Experimental Evidence from Bangladesh

\author{
Akhter Ahmed \\ John Hoddinott \\ Shalini Roy \\ Esha Sraboni
}

Poverty, Health, and Nutrition Division 


\section{INTERNATIONAL FOOD POLICY RESEARCH INSTITUTE}

The International Food Policy Research Institute (IFPRI), established in 1975, provides research-based policy solutions to sustainably reduce poverty and end hunger and malnutrition. IFPRI's strategic research aims to foster a climate-resilient and sustainable food supply; promote healthy diets and nutrition for all; build inclusive and efficient markets, trade systems, and food industries; transform agricultural and rural economies; and strengthen institutions and governance. Gender is integrated in all the Institute's work. Partnerships, communications, capacity strengthening, and data and knowledge management are essential components to translate IFPRI's research from action to impact. The Institute's regional and country programs play a critical role in responding to demand for food policy research and in delivering holistic support for country-led development. IFPRI collaborates with partners around the world.

\section{AUTHORS}

Akhter Ahmed (a.ahmed@cgiar.org is a Senior Research Fellow in the Poverty, Health, and Nutrition Division of the Internationl Food Policy Research Insitute (IFPRI) and the Country Representative for IFPRI in Dhaka, Bangladesh.

John Hoddinott (jfh246@cornell.edu) is the H.E. Babcock Professor of Food and Nutrition Economics and Policy in the Division of Nutrition Sciences at Cornell University and a Non-Resident Fellow at IFPRI.

Shalini Roy (s.roy@cgiar.org) is a Research Fellow in the Poverty, Health, and Nutrition Division at IFPRI, Washington, DC.

Esha Sraboni (esha_sraboni@brown.edu) is a Ph.D. candidate in the Department of Sociology at Brown University, Providence, Rhode Island.

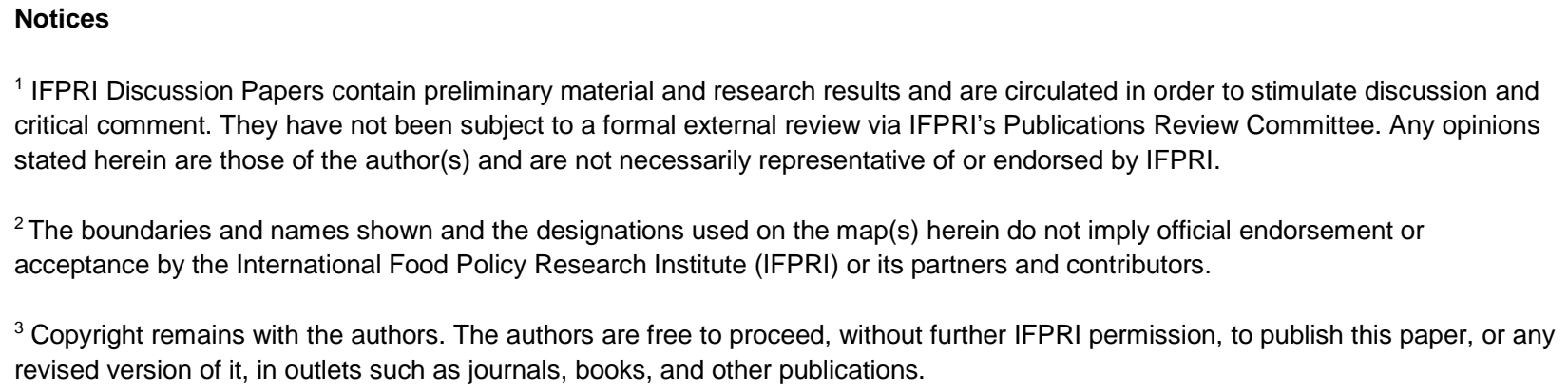




\title{
Transfers, nutrition programming, and economic well-being: Experimental evidence from Bangladesh ${ }^{\dagger}$
}

\author{
Akhter Ahmed ${ }^{\text {a }}$ \\ John Hoddinott ${ }^{b}$ \\ Shalini Roy ${ }^{\mathrm{c}^{*}}$ \\ Esha Sraboni ${ }^{\mathrm{d}}$
}

October 17, 2019

\begin{abstract}
$\dagger$ This work was undertaken as part of the CGIAR Research Program on Policies, Institutions, and Markets (PIM) led by the International Food Policy Research Institute (IFPRI). Funding support for this study was provided by PIM. The study builds on research funded by the German Ministry for Economic Cooperation and Development (BMZ), the UK's Department for International Development (DFID), the Swiss Agency for Development and Cooperation (SDC), the United Nations Development Programme (UNDP), and the United States Agency for International Development (USAID).

${ }^{a}$ Poverty, Health, and Nutrition Division, International Food Policy Research Institute (IFPRI), Dhaka, Bangladesh; ${ }^{b}$ Division of Nutrition Sciences, Cornell University, Ithaca, New York, USA; ${ }^{c}$ Poverty, Health, and Nutrition Division, International Food Policy Research Institute (IFPRI), Washington, DC, USA; ${ }^{\mathrm{d}}$ Department of Sociology, Brown University.

* Corresponding author: s.roy@cgiar.org, 1-202-862-4640.
\end{abstract}




\begin{abstract}
:
Interest has grown in leveraging cash transfer programs with nutrition interventions to improve child nutrition at scale. However, little is known about how doing so affects household economic well-being. We study a program providing cash or food transfers, with or without nutrition behavior change communication (BCC), to poor women in rural Bangladesh. We find that adding BCC to cash or food transfers leads to larger impacts on both consumption and assets an apparent puzzle, given the transfer value is unchanged. Evidence suggests this occurs through the BCC inducing increases in income generation - plausibly by improving households' social capital and empowerment.
\end{abstract}

Keywords: Cash transfers, food transfers, nutrition, behavior change communication, social protection, food security, asset accumulation, livelihoods, Bangladesh

\title{
Acknowledgments:
}

We thank DATA for careful data collection, Wahid Quabili for excellent research assistance, and Harold Alderman and Bastien Koch for helpful comments. All errors are our own. The study is registered with ClinicalTrials.gov (ID: NCT02237144), received ethical approval from the Institutional Review Board of the International Food Policy Research Institute (IFPRI), Washington, DC, and was reviewed by the Ministry of Food and Disaster Management in Bangladesh. 


\section{Introduction}

A large literature documents that cash transfers and food transfers increase household consumption. A meta-analysis of this literature from developing regions by Hidrobo et al. (2018) shows that, on average, such programs increase the value of food consumption by $13 \% .{ }^{1}$ Bastagli et al. (2016) in their review of cash transfers find consistent evidence that cash transfers increase households' total consumption and food consumption. A smaller but substantial body of evidence demonstrates that cash and food transfers also significantly increase asset holdings. Hidrobo et al. (2018) find in their meta-analysis that participation in such programs significantly increases livestock holdings by $12 \%$, non-farm productive assets by $7 \%$, farm productive assets by $53 \%$, and savings by $61 \%$.

The effectiveness of cash and food transfer programs in improving these outcomes, as well as their cost-effectiveness in reaching large numbers of poor households, has led to growing interest in leveraging them with complementary interventions, with the aim of improving other outcomes such as child nutrition at scale. Ruel and Alderman (2013) for example argue that efforts to accelerate progress on nutrition will require coupling nutrition-specific interventions with programming in other "nutrition-sensitive" sectors that address underlying causes of undernutrition - such as social protection.

It is an open question however how adding complementary programming such as nutrition-specific interventions to transfer programs - for example, in "cash plus" programs (Roelen et al. 2017) - will affect well-being in terms of household economic outcomes, relative to transfers alone. To the extent that complementary programming aims to induce greater use of transfer resources toward food consumption, there may be an offsetting reduction in household investment in assets. Given the role of assets in helping households to escape from poverty traps (Carter and Barrett 2006), this could have longer-term implications for poverty reduction. As such, this kind of complementary programming could induce a tradeoff from greater investment in physical capital toward greater investment in human capital.

To our knowledge, there is no study that rigorously studies this issue. In part, this is due to the design of most studies that assess transfer programs with complementary programming.

\footnotetext{
${ }^{1}$ Hidrobo et al (2018) review social protection broadly, but nearly all programs studied are food or cash transfers.
} 
Because the complementary programming is typically bundled with the transfer program, impacts of the transfers cannot be distinguished from impacts of the complementary programming.

In this paper, we contribute to addressing these evidence gaps. We study a program in Bangladesh that provided cash or food transfers to poor rural women, with or without complementary nutrition behavior change communication (BCC), following a randomized controlled trial design. In a companion paper, Ahmed et al. (2019) show that the combination of cash transfers and $\mathrm{BCC}$ in this program significantly improved child nutritional status, while transfers alone did not, demonstrating the importance of added BCC for nutrition objectives. In this paper, we assess its implications for economic outcomes. We compare the impacts of each treatment on both household consumption and household asset holdings after two years of program implementation. We find that both cash and food transfers increase household consumption and household assets, consistent with existing evidence, although food improves some measures of household diet more than cash, and cash increases asset accumulation more than food. However, the addition of BCC to either modality leads to larger impacts on both consumption and assets. This is counter to the hypothesized tradeoff described above and represents an apparent puzzle, given that adding BCC does not change the transfer value. We present suggestive evidence that this occurs through the BCC inducing changes in livelihoods strategies and leads to greater income generation - plausibly due to improvements in households' social capital and empowerment arising from the structure of the BCC. As such, we hypothesize that the BCC induces households to "grow the pie" using their transfer resources rather than to merely "split the pie differently."

The paper proceeds as follows. Section 2 outlines our study design and the interventions that we assess. Section 3 describes our data, and Section 4 presents our estimation strategy. Section 5 presents our main results, while Section 6 explores plausible mechanisms that underlie these. Section 7 discusses the findings and concludes. Additional material is available in appendices. 


\section{Study context}

\subsection{Study design}

The Transfer Modality Research Initiative (TMRI) was a pilot safety net program based on two cluster randomized control trials (RCTs) in rural Bangladesh: one in the northwest region (the "North") and one in the coastal southern region (the "South"). The North in the study is characterized by better market conditions but higher pre-program poverty, while the South is characterized by less poverty but greater susceptibility to weather shocks and less market access. In the North, study villages were randomly assigned to a control group or to one of four treatment arms in which beneficiaries received a cash transfer ("Cash"), a food ration ("Food"), a half cash transfer and half food ration ("Cash\&Food"), or a cash transfer along with nutrition BCC ("Cash+BCC"). In the South, study villages were also randomly assigned to a control group or to one of four treatment arms; the first three treatment groups were the same as in the north. In the fourth treatment group in the South, instead of a cash transfer along with nutrition $\mathrm{BCC}$, beneficiaries received a food ration along with nutrition $\mathrm{BCC}$ ("Food+BCC"). ${ }^{2}$

All beneficiaries were poor households with a child aged 0-24 months in March 2012. The mother of the child aged 0-24 months was the designated beneficiary - both the cardholder for receiving transfers and the target participant in BCC activities. Transfer payments and BCC were undertaken for 24 months, from May 2012 to April 2014.

The program was designed and evaluated by the International Food Policy Research Institute (IFPRI) and implemented by the United Nations' World Food Program (WFP). WFP managed the procurement and delivery of transfers, as well as the nutrition BCC training, and routinely monitored the program. An NGO contracted by WFP, the Eco-Social Development Organization (ESDO), was responsible for the field implementation of project activities, including distributing the monthly food and cash transfers, and delivering the nutrition BCC.

\subsection{Randomization and sample design}

To implement TMRI's cluster randomized control trial design, analogous sampling processes were followed in the North and in the South. In each region, five sub-districts (upazilas) were randomly selected from a list of upazilas where, according to the 2010 Bangladesh Poverty Map

\footnotetext{
${ }^{2}$ A pure BCC arm was not included, as a large RCT focusing solely on the impacts of BCC on child and maternal nutrition ("Alive and Thrive"; see Menon et al. (2016)) was concurrently underway in Bangladesh.
} 
prepared by the Bangladesh Bureau of Statistics, the proportion of households living below the lower poverty line in Bangladesh was 33 percent or more. ${ }^{3}$ All villages within these five upazilas were listed. Villages with fewer than 125 households or villages that were considered peri-urban were dropped. In each region, simple random sampling was used to assign 50 villages from this list to each of the four treatment groups and to the control group, and to assign 25 villages as reserve. In the 250 selected villages in each region, a village census was carried out, which collected information on household demographics, poverty indicators, and whether households were participating in social safety net and other targeted interventions.

From these data, a list of households was constructed that were considered poor (i.e., estimated to have consumption below the lower poverty line in Bangladesh); had a child aged 024 months in March 2012; and were not receiving benefits from any other social safety net interventions. These were the eligible households for participation in the pilot study. From each village, 10 households meeting these three conditions were randomly selected using simple random sampling, giving a total sample size of 5,000 targeted households.

\subsection{Transfers}

Beneficiaries in the "Cash" arms received a monthly payment of 1,500 Taka (approximately 19 USD) per household. Beneficiaries in the "Food" arms received a monthly food ration of 30 kilograms (kg) of rice, $2 \mathrm{~kg}$ of mosoor pulse (a lentil), and 2 liters of micronutrient-fortified cooking oil. These quantities were chosen so that the initial value of the food ration was equal to the value of the cash transfer of the beneficiaries in the "Cash" treatment arms. Beneficiaries in the "Cash\&Food" treatment arms received half of each of the two types of transfers: 750 Taka, $15 \mathrm{~kg}$ of rice, $1 \mathrm{~kg}$ of mosoor pulse, and 1 liter of micronutrient-fortified cooking oil.

Cash and food transfers were delivered to women during the second week of every month. Cash was delivered using a mobile phone cash transfer system, in which women

\footnotetext{
${ }^{3}$ In Bangladesh, households below the lower poverty line represent the extreme poor. The official lower poverty line identifies the extreme poor households whose total household expenditures are below the food poverty line. The food poverty line represents the cost of acquiring a basic food basket that provides the minimum nutritional requirement of 2,122 kilocalories per person per day.
} 
collected cash from designated distribution sites using mobile verification of identity. ${ }^{4}$ Food transfers were handed to beneficiaries at designated food distribution points. Cash and food distribution points were no more than 2 kilometers from participants' homes (Ahmed et al. 2016).

\subsection{Behavior change communication}

The beneficiaries of the "Cash+BCC" arm in the North and of the "Food+BCC" arm in the South received the same transfer as in the "Cash" only and "Food" only treatment groups, respectively, as well as a suite of intensive nutrition BCC interventions focused on education and behavior change at the household and community level (Ahmed et al. 2016). The BCC intervention involved three complementary activities: (1) weekly group BCC trainings - some with beneficiaries only (i.e., the target women in the Food $+\mathrm{BCC}$ or Cash+BCC groups) and some that invited other family members to attend along with beneficiaries, (2) twice-a-month visits by community nutrition workers (CNWs) to the beneficiaries' homes, and (3) monthly group meetings between program staff and influential community leaders.

The group BCC trainings only for beneficiaries occurred on the day of the transfer distribution, once a month. For the remaining group BCC trainings each month, other household members - particularly mothers-in-law, husbands, and other pregnant or lactating women - were invited to attend along with beneficiaries, with the intention of creating a supportive household atmosphere and behavior change at the household level. These combined sessions served to facilitate women's ability to participate in the BCC, as household members could see what women were participating in and reduce restrictions on attendance, and to increase uptake of BCC messages as husbands and mothers-in-law are also key decision makers on food purchases, infant and young child feeding (IYCF), and child-rearing in the household.

About 9-15 beneficiaries were part of each group. The group trainings took place no further than $2 \mathrm{~km}$ from beneficiaries' homes and lasted approximately one hour, on average. Monitoring data showed that beneficiaries assigned to a BCC intervention attended on average 48 of the scheduled 52 sessions per year in the North and 49 of the scheduled 52 sessions per year in the South. Trainings covered the following topics: basic nutrition, control and prevention

\footnotetext{
${ }^{4}$ Since this method used a mobile phone handset and SIM card, to preserve the design of the experiment, these were provided to all women in the study (in all treatment and control arms).
} 
of micronutrient deficiencies, IYCF practices, health care, maternal nutrition, and hygiene. The BCC training was led by CNWs, engaged by ESDO. CNWs were trained by WFP and ESDO to impart the BCC content using a variety of methods including question and answer, flashcards, real-life examples, discussions, practical demonstrations, role-playing, and songs. ${ }^{5}$ Anecdotally, the interactive nature of the sessions led to a lively atmosphere and solidarity among participants. On field visits, researchers observed women arriving early at sessions and leaving late in order to talk with other members.

CNWs also conducted the twice-per-month home visits to observe household-level practice and encourage the adoption of positive behaviors, as well as followed up with home visits for individual counseling to beneficiaries on an as-needed basis. Attendance at the group BCC sessions was a soft condition of receipt of the transfers; when a mother missed a session, a CNW would follow up with a home visit to uncover what the reason was for missing the session and to convey the missed information, and no beneficiaries were dropped from the study for failing to attend sessions.

The monthly group meetings with influential community members (such as village heads, religious leaders, school teachers, community elected persons, and local health and family planning staff) were conducted by CNWs and ESDO staff, without the beneficiaries present, to explain the purpose and importance of the BCC and to provide them with the information being conveyed to study participants. The aim of these meetings was, similar to inviting other household members to group BCC trainings, to facilitate women's participation and to increase uptake of messages through a supportive community environment.

Of note, there was no explicit focus on livelihoods or income generation in any of the BCC components. Discussions included the importance of fruits, vegetables, and animal source foods and how access to these could be facilitated through homestead gardens or livestock/poultry-rearing, but the emphasis was on how to acquire nutritious foods for the child rather than on building livelihoods more generally. There was also no broader discussion of resource management or allocation of transfers to uses such as savings, assets, or debt repayment.

\footnotetext{
${ }^{5}$ The BCC component was designed specifically for TMRI by WFP in consultations with IFPRI and local technical experts. Session materials were derived in part from material developed for Alive \& Thrive (A\&T) in Bangladesh.
} 


\section{Data}

\subsection{Data collection}

Quantitative data collection for the impact evaluation of TMRI included three rounds of longitudinal surveys: a baseline survey in March-April 2012 prior to the start of intervention in May 2012, a midline survey in June 2013, and an endline survey in April 2014 just before the end of intervention. ${ }^{6}$ From October-December 2012, a qualitative and quantitative process evaluation was conducted, collecting information on the implementation of the interventions and beneficiaries' experience with the program.

The baseline, midline, and endline surveys attempted to interview all 5,000 households that were included in TMRI treatment or control groups in the North or South. Surveys were multi-topic, including extensive modules on household demographic and socioeconomic characteristics including food consumption and individual dietary recall as well as non-food consumption, savings, assets, labor, and livelihoods activities; knowledge and practices regarding child nutrition and hygiene; and women's status. In the baseline survey, the youngest child in the household aged 0-24 months in March 2012 was identified as an "index" child. Modules were designated as to be answered by either a male (usually the household head and almost always the index child's father), who was interviewed by a male enumerator, or a female (the index child's primary female caregiver, almost always the index child's mother), who was interviewed by a female enumerator.

\subsection{Outcome measures}

We analyze the following outcomes related to household consumption: the value of monthly food consumption, the value of non-food consumption, and the value of total consumption (Deaton et al. 2002). Food consumption is constructed based on a module eliciting information on all food consumed or purchased by the household in the seven days preceding the survey. Non-food consumption includes expenditures on, e.g., fuel, toiletries, transportation, clothing and footwear, rent and utilities, health expenses, education expenses, etc.

In an appendix, we also assess impacts on variables related to household diet: per capita daily caloric intake, food poverty, food consumption score (FCS), low FCS, and the value of

\footnotetext{
${ }^{6}$ A post-endline survey from October 2014 to February 2015, 6 to 10 months after the intervention ended, focused on early childhood development and intimate partner violence and is not used in this paper.
} 
monthly food expenditure per capita. Caloric intake is constructed from 24-hour dietary recall data. The 24-hour dietary recall module asked the female household member primarily in charge of cooking, supervising, and serving food about all the foods consumed the previous day (or the last "normal" day if the previous day was one where special foods were eaten) by herself or anyone else in the household, during the day and night, whether at home or outside the home. For each dish reported, the enumerator collected information on the ingredients, the raw weight of the ingredients, and the cooked weight of the ingredients. Daily household caloric intake was then constructed based on food composition tables and converted to per capita using household size. Food poverty is defined as per capita daily caloric intake below 2122 calories (Bangladesh Bureau of Statistics 2011). The FCS is an indicator developed by WFP that combines information on which of seven different food groups was consumed by a household in the preceding 7 days, the frequency with which each of these food groups was consumed, and a weight on each food group intended to reflect its nutritional importance (World Food Program 2008). The FCS ranges from 0 to 112, where higher values are better. Low FCS is defined as FCS below 35, per WFP's guidelines.

The outcomes we analyze related to assets include the following: total assets, loans, and net assets. An assets module was administered asking about ownership of a range of assets including livestock, poultry, productive non-animal assets, consumer durables, and cash-in-hand - then asking the present value for any asset owned. For our measure of total assets, savings was added to these. For our measure of net assets, loans were subtracted from total assets.

To assess impacts on livelihoods and income, we assess the following outcomes: household total labor income, total private transfers received, total public transfers received, and estimated "net" income. Labor income is measured using a module that collects information on all economic work performed by each household member in the preceding 7 days, including occupation, then asks or imputes the monthly income from each activity. Income from these activities is first grouped into agricultural wage income, non-agricultural wage income, own farm labor income, or non-farm self-employment income, then aggregated. Information on the value of private transfers received (cash or in-kind) is collected over a 1-year period and includes international remittances received from relatives, domestic remittances received from relatives, charity and other assistance, and dowry. Information on the value of public transfers received (cash or in-kind) is also collected over a 1-year period and includes cash or in-kind assistance 
received from each of a list of social safety net programs ongoing in Bangladesh during the study period. The estimated net income is calculated by adding total labor income to total private transfers received and total public transfers received. ${ }^{7}$ Each of these measures is imputed to monthly for our estimation.

\subsection{Estimation sample}

Our sample for estimating the impacts of TMRI includes all households that were successfully re-interviewed and have non-missing information on our key outcomes at endline: 2395 in the North and 2425 in the South. Attrition from the baseline sample to the endline estimation sample is thus $4.2 \%$ over two years in the North and $3 \%$ over two years in the South. Regressing a dummy variable for attrition on the intervention arms in the full sample reveals that the attrition rate does not differ significantly across arms (Appendix Table A1). Comparing mean differences in households' baseline characteristics within the non-attrited estimation sample shows that these also do not differ significantly across arms (Appendix Table A2).

\section{Estimation strategy}

We take advantage of the study's experimental design and conduct an intent-to-treat (ITT) analysis using analysis of covariance (ANCOVA) estimation with baseline and endline data (McKenzie 2012). The randomized assignment and balance in baseline characteristics minimize concerns of bias.

In our estimation, we take into account the cluster-randomized study design. We estimate the following regression model in the North, using ordinary least squares:

$$
Y_{i v, e}=\propto+\delta Y_{i v, b}+\beta_{1} \text { Food }_{v}+\beta_{2} \operatorname{Cash}_{v}+\beta_{2} \text { FoodCash }_{v}+\beta_{2} \operatorname{CashBCC}_{v}+\varepsilon_{i v, e}
$$

where $Y_{i v, e}$ is the outcome of interest for household $i$ from village $v$ at endline, $Y_{i v, b}$ is the same outcome of interest for household $i$ from village $v$ at baseline, and $\varepsilon_{i v, e}$ is the error term for household $i$ from village $v$ at endline. Food $_{v}$, Cash $_{v}$, FoodCash $_{v}$, CashBCC $_{v}$ are indicators that equal one if village $v$ is assigned to the Food, Cash, Food \& Cash, and Cash $+\mathrm{BCC}$ treatment arms, respectively. $\beta_{1}, \beta_{2}, \beta_{3}$, and $\beta_{4}$ represent ITT estimators, or the effects of being assigned to the Food, Cash, Food \& Cash, and Cash $+\mathrm{BCC}$ arms relative to the control group, respectively.

\footnotetext{
${ }^{7}$ Although some households may have other sources of income, we use this measure as a proxy.
} 
We estimate the analogous regression model in the South, with Food $+\mathrm{BCC}$ replacing Cash+BCC, using ordinary least squares:

$$
Y_{i v, e}=\propto+\delta Y_{i v, b}+\beta_{1} \text { Food }_{v}+\beta_{2} \text { Cash }_{v}+\beta_{2} \text { FoodCash }_{v}+\beta_{2} \text { FoodBCC }_{v}+\varepsilon_{i v, e}
$$

To test whether $\beta_{1}, \beta_{2}, \beta_{3}$, and $\beta_{4}$ are statistically different from each other in each region, we conduct Wald tests of equality and report the p-values. In all regressions, we adjust standard errors for clustering at the village level, which was the level of randomization. In all regressions, we include a dummy for missing baseline outcomes in order to increase the estimation sample.

\section{Results}

\subsection{Impacts on household consumption}

Table 1 presents the main impact estimates of TMRI in the North and in the South on household consumption. We find that, consistent with existing evidence, both cash and food significantly increase consumption in both regions, driven mostly by increases in food consumption. Cash in the North leads to a significant increase of about 140 taka per capita monthly in food consumption (representing a 17\% increase from the control mean) and about 175 taka per capita monthly in total consumption (a 13\% increase from the control mean); the impact of Food and the impact of Cash\&Food do not significantly differ from this. However, Cash+BCC in the North leads to significantly larger impacts on food consumption (an increase of about 340 taka, or a $42 \%$ increase from the control mean), non-food consumption (about 64 taka, or a 13\% from the control), and total consumption (about 395 taka, or a 30\% increase from the control) than all other treatment arms. We see an analogous pattern in the South. Cash and food significantly increase consumption in both regions, driven by increases in food consumption, but Food $+\mathrm{BCC}$ impacts are significantly larger than those of all other treatments in the South.

For insight into how this translates to impacts on household diet, we also show impacts on per capita daily caloric intake, food poverty, FCS, and low FCS in Appendix Table A3. Appendix 1 describes these results in detail. In short, in the North, estimates reveal that all treatments significantly improve nearly all indicators assessed. Food has similar or even larger impacts on diet indicators than Cash, with significant differences from cash in terms of impacts on caloric intake, on FCS, and prevalence of low FCS. However, the impacts of Cash $+\mathrm{BCC}$ in the North on all of these household diet indicators are significantly larger than the impacts of any 
other treatment, and by a substantial magnitude. In the South, where the control group's dietary indicators are considerably better on average than in the North, effects are more modest. The Food arm again has similar or slightly larger impacts on diet indicators than Cash, with significant differences from Cash in terms of the impact on FCS. Like Cash+BCC in the North, Food $+\mathrm{BCC}$ in the South has significantly larger impacts on diet indicators than any other treatment, by a substantial magnitude.

\subsection{Impacts on household asset holdings}

The large differences in impacts on consumption between treatments with BCC and those without $\mathrm{BCC}$ raise the possibility that there may be tradeoffs in other outcomes, such as household assets. Table 2 looks at impacts on household asset holdings (including cash-in-hand and savings), loans, and "net" assets (assets holdings minus loans). In the North, Cash and Food both significantly increase asset holdings, in terms of both total assets and net assets. However, Cash + BCC leads to significantly larger impacts than all other treatments - increasing total assets by over 18,000 taka or over $70 \%$ of the control mean. In the South, Cash (but not Food) significantly increases asset holdings, but Food+BCC leads to significantly larger impacts than all other treatments.

Taken together, the results in Tables 1 and 2 are both compelling and potentially surprising. We find modest differences between Cash and Food, with Food leading to significantly higher impacts on some household diet indicators in both the North and the South, and Cash leading to significantly larger increases in assets in the South. In both regions, the addition of nutrition BCC leads to strikingly larger impacts on consumption; however, these do not appear to be offset by smaller impacts on asset accumulation. We find this pattern in both regions, though more strongly in the North.

These findings suggest two possibilities. One possibility is that households receiving BCC in both the North and the South are systematically overstating their well-being in terms of indicators related to both consumption and assets. Although we cannot rule out this possibility, we believe it is unlikely to drive our results for several reasons. First, although social desirability (Phillips and Clancy 1972) could plausibly lead participants receiving nutrition BCC to report

food consumption behaviors consistent with what was recommended in the BCC, in a companion paper, we find that the patterns by treatment found in the household consumption module 
(reported by the male household head) are not only consistent with patterns found in child feeding modules (reported separately by the female) but are also consistent with differing treatment impacts found on objective measurements of child anthropometry (Ahmed et al. 2019). Second, the BCC sessions did not promote using the transfers toward accumulating assets, increasing savings, or paying off loans; thus, we would not expect social desirability to lead male heads in BCC households to systematically overreport on questions related to these.

The second possibility is that the patterns of impact shown in Tables 1 and 2 are driven by BCC treatment households not simply allocating their equal-value transfers differently than non-BCC treatment households, but using these equal-value transfers in a way that increases their overall resources. In other words, BCC treatment households may not merely "split the pie" differently than non-BCC treatment households, but "growing the pie" more than non-BCC treatment households. This could occur if - despite the BCC not being intended for this purpose - the BCC treatment households were more likely to use part of their transfers for income generation through changes in livelihoods. The next section explores the evidence for such effects.

\subsection{Impacts on household income and livelihoods}

Table 3 assesses how the various treatments affect measures of household income - in terms of monthly imputations of household labor income, private transfers to the household, public transfers to the household, and estimated "net" household income. In the North, we see that the cash, food, and combined cash and food arms have no significant impact on households' total labor income. However, Cash+BCC significantly increases monthly total labor income - by about 458 taka, an 11\% increase relative to the control. There are no statistically significant changes in private transfers or public transfers in any of the arms, leading to significant increases in net household income from Cash+BCC (about 615 taka, a 14\% increase from the control). In the South, we see that the cash and Food + BCC arms both have significant impacts on total household labor income, of 494 taka (about 10\% increase) and 574 taka (about 12\% increase), respectively. However, there are meaningful reductions in private transfers (borderline significant in some arms and not significantly different across treatment arms), and small but significant reductions in public transfers, leading to a smaller borderline significant increase of 
about 400 taka in estimated net income from Food + BCC in the South (about a 7\% increase from the control group mean).

To shed light on how changes in livelihoods might underlie these effects, Table 4 breaks down the impact on monthly household labor income across its component categories: agricultural wage income, non-agricultural wage income, own farm labor income, and non-farm self-employment income. In the North, the increase in household labor income from Cash $+\mathrm{BCC}$ appears driven by large significant increases in labor income from own farm work (about 428 taka, or nearly a 60\% increase) and from non-farm self-employment (375 taka, or about a 28\% increase), partially offset by a borderline significant reduction in labor income from agricultural wage work (300 taka, or about 23\% decline). Although cash shows a similar pattern agricultural wage income significantly decreases, while non-farm self-employment income and own farm income significantly increase - the magnitudes are smaller, particularly for own farm income, thus overall there is no statistically significant increase in total labor income. Meanwhile in the South, the increases in labor income from Cash and Food+BCC appear driven by a combination of small increases (mostly not individually statistically significant) across agricultural wage income, own farm labor income, and non-farm self-employment income. Food only and the combination of food and cash show no statistically significant increase in total labor income or any of its components.

To then understand the differing effects on private transfers, Table 5 breaks down the impact across its component categories. In the North, we see approximately 53\% of the control group in the North receives private transfers over the preceding 12 months, on average about 300 taka, driven almost entirely by remittances from domestic relatives; there appears to be little crowding out of these from the program. In the South, the proportion of control households receiving private transfers over the preceding 12 months is similar to the North (about 54\%), and these also are driven by remittances from domestic relatives. However, the average value of domestic remittances in the South is much higher at nearly 740 taka (almost half of monthly total consumption per capita), and results indicate large reductions in these of about 200 taka (in some cases borderline significant) across all arms, suggesting much stronger crowding out. ${ }^{8}$

\footnotetext{
${ }^{8}$ Presenting a breakdown of impacts on public transfers is not straightforward, as over 40 programs were asked about. However, the small reduction in public transfers in the South due to TMRI appears driven by average reductions in transfers received from the Vulnerable Group Development (VGD) program, which provides food
} 
Taking together the results from Tables 3 to 5, our evidence indicates that in the North, Cash + BCC led to significant increases in total household income, due to large increases in household labor income and no meaningful reduction in public or private transfers. The increases in labor income from Cash $+\mathrm{BCC}$ in the North were driven by a reduction in agricultural wage income and increases in own farm labor income and non-farm self-employment income. Meanwhile, in the South, there is a smaller borderline significant increase in total household income, due to large increases in household labor income but also significant crowding of private transfers (particularly domestic remittances). The increases in labor income from Food $+\mathrm{BCC}$ in the South were driven by relatively small (and not individually statistically significant) increases across agricultural wage income, own farm income, and non-farm self-employment income. Overall, findings support the hypothesis that Cash $+\mathrm{BCC}$ in the North and Food $+\mathrm{BCC}$ in the South increase both consumption and assets relative to other arms due to differential increases in household labor income; in the case of the South, these are partially offset by reduced remittances received, while there is no such effect in the North.

\section{Mechanisms}

The findings above raise the question of how and why certain intervention arms - particularly those including BCC - led to changes in livelihoods. Although we cannot conclusively provide an answer, we explore suggestive evidence.

Motivated by the pattern of impacts on labor income, we first consider whether the addition of BCC led to greater investment in assets relevant to own farm work or selfemployment. Table 6 shows the impacts of various treatments on different categories of assets. In the North, consistent with increases in own farm work across several arms - particularly in those receiving cash, and strongest in Cash $+\mathrm{BCC}$ - we see significant increases in livestock ownership across all arms but particularly in those receiving cash, and largest in Cash+BCC. Similarly, we see significant increases in poultry ownership in arms receiving cash, and largest in Cash $+\mathrm{BCC}$. These results suggest that, in the North where agroecological conditions favor

\footnotetext{
rations and other services to ultra-poor rural women in Bangladesh. The control group in the South receives a higher average value of transfers from VGD than the control group in the North, implying greater potential for crowding out in the South.
} 
animal rearing, cash was better able than food to mobilize investments in livestock and poultry, and the addition of BCC further strengthened these.

Table 6 further shows that, in the North, ownership of consumer durables significantly increase in arms that receive cash - where consumer durables include items such as bicycles, rickshaws, motorcycles, push carts, etc - with impacts strongest from the Cash+BCC arm. Moreover, a similar pattern holds for having cash in hand - all arms show significant increases, but impacts are larger among those receiving cash or cash+BCC. Taken together, the increases in transport assets and cash-in-hand among cash recipient households, particularly those receiving Cash+BCC, help to explain increases in self-employment income among these groups. In the South, there are no significant impacts on ownerships of livestock and poultry, consistent with agroecological conditions, although the impacts from Food $+\mathrm{BCC}$ on these is significantly larger than from any other arm. In the South, like in the North, there are increases in ownership of consumer durables - with impacts largest from Food $+\mathrm{BCC}-$ and on cash-in-hand, again potentially supporting increases in self-employment.

We next assess whether the addition of BCC affected household investment in land. Given that land is scarce in rural Bangladesh and leasing land is more common as a form of investment than purchasing land, we focus on impacts on leased land. Table 7 shows that, although there are no statistically significant impacts from any treatment in the North on land leased using cash, we find a significant increase from Cash $+\mathrm{BCC}$ in the North on land leased through share cropping (about 6 decimals, nearly a 50\% increase relative to the control group), which contributes to a significant increase from Cash+BCC in total land leased (about 7 decimals, approximately a 50\% increase). These impacts are further consistent with Cash $+\mathrm{BCC}$ in the North significantly increasing labor income from own farm work. In the South, there are no significant impacts from any treatment on leased land.

Finally, Table 8 assesses whether the addition of BCC changed the types of crops that households grew, specifically whether they chose to cultivate improved rice varieties or wheat. We find that, in the North, there is a borderline significant effect of cash on cultivation of improved rice or wheat (a 7 percentage point increase, or an $18 \%$ increase relative to the control), while the impact of Cash+BCC appears larger and is statistically significant (14 percentage point increase, or a $37 \%$ increase), with the difference between arms statistically 
significant at the $10 \%$ level. ${ }^{9}$ In the South, there is a significant effect of cash on cultivation of improved rice or wheat (a 6 percentage point increase, or a 35\% increase relative to the control), which significantly differs from the impact of food. The impact from Food+BCC is not statistically significant, but is not significantly different from the impact of cash.

Taken together, results from Tables 6 to 8 suggest a narrative that in the North, where agroecological conditions are favorable to animal-rearing and crop cultivation, cash was used toward these investments, and effects were particularly strong from the Cash+BCC. These effects are consistent with the large increases we see in own farm labor income from Cash+BCC in the North. Such effects are notably absent or much weaker in the South, where agroecological conditions differ - although there is some indication that Food $+\mathrm{BCC}$ led to greater investment in livestock and poultry than the other arms.

In both the North and the South, transfers were used toward consumer durables which include transport assets - with the largest increases coming from Cash $+\mathrm{BCC}$ and Food $+\mathrm{BCC}$ arms - and led to increases in cash-in-hand. These patterns are consistent with the increases seen in non-farm self-employment income.

\section{Discussion and conclusions}

Our results indicate the following. In the North, Cash+BCC allowed households to not only increase consumption more than other treatment arms, but also to increase asset holdings more than the other arms. This plausibly occurs through Cash+BCC increasing net household income. Cash $+\mathrm{BCC}$ appears to lead to significant increases in household labor income over and above other treatment arms in several ways - through promotion of agricultural investments for households' own farms and through facilitation of self-employment - without offsetting effects in households' private transfers. Specifically, Cash+BCC households experienced larger impacts than other treatment arms on ownership of livestock, poultry, and consumer durables including transport assets; greater increases in land leased through share cropping and in total land leased; and a larger increase than other arms in cultivation of improved rice or wheat.

In the South, Food + BCC also allowed households to both increase consumption and asset holdings relative to other arms, and this appears to occur through Food $+\mathrm{BCC}$ increasing net household income as well. However, effects of Food $+\mathrm{BCC}$ in the South are more modest than

\footnotetext{
${ }^{9}$ This is notable, as the BCC did not touch upon improved agricultural technologies and production practices.
} 
those of Cash $+\mathrm{BCC}$ in the North. Consistent with this, Food+BCC did increase household labor income, but our evidence suggests considerable crowding out of domestic remittances in the South due to transfers. Food+BCC also did not have significant impacts on livestock, poultry, leased land, or cultivation of improved crop varieties, consistent with agroecological conditions.

Our findings prompt the question of why adding nutrition $\mathrm{BCC}$ to transfers induces changes in income generation and livelihoods activities. We are not able to provide a conclusive answer but propose several hypotheses. One plausible explanation is that the BCC increased households' social capital and empowerment. Roy et al. (forthcoming) suggest that the structure of the BCC itself increased social capital - by targeting women who were socially excluded due to extreme poverty and physically isolated due to female seclusion norms, then intensively engaging them in interactive groups that met weekly over the course of two years. Quantitative evidence from Hoddinott et al. (2017b) and qualitative evidence from Ahmed et al. (2014) indicate that, because of BCC-participant women's increased nutrition knowledge (Hoddinott et al. 2017a), non-participants also began interacting with them. A woman receiving BCC reports, "The neighbors regularly come over to hear what the family learned in the latest training session" and describes this as facilitating a position for them within the community, saying community members now "welcome us cordially to their house" (Ahmed et al. 2014). Roy et al. (forthcoming) show quantitative evidence that the addition of BCC moreover increased participant women's agency and self-reported confidence. Field staff from ESDO report observing a stark difference between TMRI beneficiaries who received BCC and those who did not, saying the former are less superstitious and "the doors to their brains are open" (Ahmed et al. 2014). ESDO staff also report that BCC participants adapt more quickly to mobile phone cash transfers (Ahmed et al. 2014), suggesting greater receptivity to new challenges and opportunities. Increased social capital could facilitate households' access to networks, for example, allowing greater ability to obtain share-cropping arrangements or gain access to inputs and information required for cultivating improved crop varieties or other livelihood opportunities. Greater confidence, agency, and open-mindedness could increase households' motivation to do so.

Another plausible reason for why transfers with BCC might specifically increase livestock- and poultry-rearing in both the North and South, relative to transfers alone, is its focus on the importance of young children consuming animal-source foods including dairy and eggs. 
Ahmed et al. (2019) show that indeed, relative to other arms, both Cash+BCC in the North and Food + BCC in the South significantly increase children's consumption of dairy and eggs.

A third possible explanation relates to the addition of BCC increasing beneficiary women's control over resources within the household, as shown by Roy et al. (forthcoming). If women were more likely than men to support using transfer resources for productive investments, this could explain differential patterns across the arms. ${ }^{10}$

Our results additionally raise the question of why we see differences in effects between Cash + BCC in the North and Food+BCC in the South. Given our study design, we are not able to distinguish the extent to which these differences are driven by context (regional differences in the North vs. South) vs. transfer modality (cash vs. food). However, patterns in our results suggest both play a role. In particular, the different impacts of the same modality across regions (for example, the impacts of cash on investments in livestock and poultry compared across the North and South) suggest that decisions of how to use transfer resources are strongly shaped by context. The dynamics of transfer receipt crowding out income from domestic remittances also appear very different by region. At the same time, the effects of cash alone relative to food alone within each region highlight a role for modality as well. For example, results indicate that cash may better facilitate mobilizing resources into productive investments than food.

Overall, our findings contribute evidence to several gaps in the literature and have important policy relevance. First, results show that, in the context of rural Bangladesh, cash transfers and food transfers lead to modest differences in impacts - with food causing significantly larger impacts on some dimensions of household diet, and cash leading to larger impacts on assets, but both leading to similar impacts on many other outcomes. This suggests that the choice of modality - food or cash - may hinge on policymaker objectives, consistent with previous evidence (Gentilini 2015).

\footnotetext{
${ }^{10}$ One explanation that is not supported by our evidence is that women's increased work drives the increases in household labor income. Appendix tables A4, A5, and A6 show that the increases in household labor income are driven almost exclusively by increases in adult male labor income in both the North and the South. Changes in adult female labor income appear only in the North and not the South. In the North, these are reallocations of women's labor income from nonagricultural wage income (for example, work as domestic servants) to own farm labor (most likely, taking care of livestock and poultry).
} 
Second, results highlight that context matters for impacts of transfer programs. The same modality implemented in an identical way across two regions of the same country shows very different patterns of impact in several dimensions. These include direct impacts - such as the types of assets that households invest in - as well as indirect impacts such as the extent to which there is crowding out of private transfers such as domestic remittances. Differences in impact across regions are plausibly underpinned by several factors, such as differences in agroecological conditions and differences in economic well-being in the absence of the program.

Finally, our study is, to the best of our knowledge, the first to assess whether there are tradeoffs in terms of household economic outcomes when complementary programming is added to a transfer program. In the case of TMRI in Bangladesh, we find that the addition of nutrition BCC to either cash or food leads to much larger impacts on consumption, while also leading to larger impacts on assets. Thus, we find no tradeoff from introducing nutrition BCC specifically in terms of increasing human capital investment at the expense of physical capital investment. In fact, the addition of BCC leads transfer recipients to "grow the pie" rather than merely split it differently, by inducing greater income generation. We note that, given that TMRI's BCC content was focused on nutrition, these dynamics were plausibly driven by the BCC structure, which facilitated expanding women's empowerment and households' social status and networks. Thus, we may not expect such effects to emerge from a less intensive or differently designed $\mathrm{BCC}$, and our overall pattern of findings may not generalize to complementary programming at large. Nonetheless, these findings imply TMRI's BCC led to both larger short-term and longerterm improvements in household well-being. In the face of concerns that a "Christmas tree" approach of "stringing" additional benefits on to cash transfer programs may dilute their objectives (Cecchini and Madariaga 2011), this study provides an example where additional programming strengthens impacts on core objectives and expands impacts to a wider range as well. Although estimates of the cost of TMRI's BCC component are sizeable - approximately $\$ 50$ per beneficiary per year (Ahmed et al. 2016) - the additional benefits both during and potentially after the program on a range of outcomes suggest that it may be a cost-effective component to combine with transfers. 


\section{References}

Ahmed, Akhter, John F Hoddinott, and Shalini Roy. 2019. Food Transfers, Cash Transfers, Behavior Change Communication and Child Nutrition: Evidence from Bangladesh.

Ahmed, Akhter, John F Hoddinott, Shalini Roy, Esha Sraboni, Wahidur R Quabili, and Amy Margolies. 2016. Which Kinds of Social Safety Net Transfers Work Best for the Ultra Poor in Bangladesh? Operation and Impacts of the Transfer Modality Research Initiative.

Dhaka, Bangladesh.

Ahmed, Akhter, Esha Sraboni, and Fiona K. Shaba. 2014. Safety Nets in Bangladesh: Which Form of Transfer Is Most Beneficial? Dhaka, Bangladesh.

Bangladesh Bureau of Statistics, World Bank. 2011. Bangladesh Household Income and Expenditure Survey: Key Findings and Results. Washington, D.C., and Dhaka, Bangladesh. Bastagli, Francesca, Jessica Hagen-Zanker, Luke Harman, Valentina Barca, Georgina Sturge, Tanja Schmidt, and Luca Pellerano. 2016. "Cash Transfers: What Does the Evidence Say? A Rigorous Review of Programme Impact and of the Role of Design and Implementation Features." (July): 300.

Carter, Michael R., and Christopher B. Barrett. 2006. "The Economics of Poverty Traps and Persistent Poverty: An Asset-Based Approach.” Journal of Development Studies 42(2): 178-99.

Cecchini, Simone, and Aldo Madariaga. 2011. 17 Conditional Cash Transfer Programmes: The Recent Experience in Latin America and the Caribbean.

Deaton, Angus, Salman Zaidi, Martha Ainsworth, Javier Ruiz-Castillo, Lionel Demery, Paul Glewwe, Margaret Grosh, Jesko Hentschel, Manny Jimenez, Jean Olson Lanjouw, Raylynn Oliver, Giovanna Prennushi, Martin Ravallion, Kinnon Scott, and Naoko Watanabe. 2002. Guidelines for Constructing Consumption Aggregates For Welfare Analysis. Washington D.C.

Gentilini, Ugo. 2015. “Revisiting the 'Cash versus Food' Debate: New Evidence for an Old Puzzle?" The World Bank Research Observer: 1kv012.

Hidrobo, Melissa, John Hoddinott, Neha Kumar, and Meghan Olivier. 2018. "Social Protection, Food Security, and Asset Formation.” World Development 101: 88-103.

Hoddinott, John, Akhter Ahmed, Naureen I. Karachiwalla, and Shalini Roy. 2017a. "Nutrition Behaviour Change Communication Causes Sustained Effects on IYCN Knowledge in Two 
Cluster-Randomised Trials in Bangladesh." Maternal \& Child Nutrition: e12498.

Hoddinott, John, Ishita Ahmed, Akhter Ahmed, and Shalini Roy. 2017b. "Behavior Change

Communication Activities Improve Infant and Young Child Nutrition Knowledge and

Practice of Neighboring Non-Participants in a Cluster-Randomized Trial in Rural

Bangladesh” ed. Frank Wieringa. PLOS ONE 12(6): e0179866.

McKenzie, David. 2012. "Beyond Baseline and Follow-up: The Case for More T in

Experiments." Journal of Development Economics 99(2): 210-21.

Menon, Purnima, Phuong Hong Nguyen, Kuntal Kumar Saha, Adiba Khaled, Tina Sanghvi, Jean

Baker, Kaosar Afsana, Raisul Haque, Edward A Frongillo, Marie T Ruel, and Rahul Rawat.

2016. "Combining Intensive Counseling by Frontline Workers with a Nationwide Mass

Media Campaign Has Large Differential Impacts on Complementary Feeding Practices but

Not on Child Growth: Results of a Cluster-Randomized Program Evaluation in

Bangladesh." The Journal of Nutrition 146(10): 2075-84.

Phillips, Derek L., and Kevin J. Clancy. 1972. "Some Effects of 'Social Desirability' in Survey

Studies." American Journal of Sociology 77: 921-40.

Roelen, Keetie, Stephen Devereux, Abdul-gafaru Abdulai, Bruno Martorano, Tia Palermo, and

Luigi Peter Ragno. 2017. How to Make 'Cash Plus 'Work: Linking Cash Transfers to

Services and Sectors.

Roy, Shalini, Melissa Hidrobo, John Hoddinott, and Akhter Ahmed. "Transfers, Behavior

Change Communication, and Intimate Partner Violence: Post-Program Evidence from Rural

Bangladesh." The Review of Economics and Statistics: In press.

Ruel, Marie T, and Harold Alderman. 2013. "Nutrition-Sensitive Interventions and Programmes:

How Can They Help to Accelerate Progress in Improving Maternal and Child Nutrition?"

The Lancet 382(9891): 536-51.

World Food Program. 2008. Food Consumption Analysis: Calculation and Use of the Food

Consumption Score in Food Security Analysis. Rome. 
Table 1: Impact of treatment on household consumption

\begin{tabular}{|c|c|c|c|c|}
\hline & & $\begin{array}{l}\text { Food consumption per capita } \\
\text { (monthly) }\end{array}$ & $\begin{array}{l}\text { Non-food consumption per capita } \\
\text { (monthly) }\end{array}$ & $\begin{array}{l}\text { Total consumption per capita } \\
\text { (monthly) }\end{array}$ \\
\hline \multirow[t]{13}{*}{ North } & Cash & $\begin{array}{c}138.04 \\
(28.19)^{* * *}\end{array}$ & $\begin{array}{c}37.35 \\
(19.78)^{*}\end{array}$ & $\begin{array}{c}175.47 \\
(40.35)^{* * *}\end{array}$ \\
\hline & Food & $\begin{array}{c}120.68 \\
(30.14)^{* * *}\end{array}$ & $\begin{array}{c}56.24 \\
(22.61)^{* *}\end{array}$ & $\begin{array}{c}179.48 \\
(45.13)^{* * *}\end{array}$ \\
\hline & Cash and food & $\begin{array}{c}107.69 \\
(26.70)^{* * *}\end{array}$ & $\begin{array}{l}18.15 \\
(22.24)\end{array}$ & $\begin{array}{c}127.03 \\
(42.28)^{* * *}\end{array}$ \\
\hline & $\mathrm{Cash}+\mathrm{BCC}$ & $\begin{array}{c}338.63 \\
(29.40)^{* * *}\end{array}$ & $\begin{array}{c}64.11 \\
(23.84)^{* * *}\end{array}$ & $\begin{array}{c}395.21 \\
(46.13)^{* * *}\end{array}$ \\
\hline & $R^{2}$ & 0.11 & 0.14 & 0.13 \\
\hline & $N$ & 2,395 & 2,395 & 2,395 \\
\hline & Mean of Control & 813.31 & 491.59 & 1304.91 \\
\hline & P-value: $\mathrm{Cash}=\mathrm{Cash}+\mathrm{BCC}$ & 0.00 & 0.26 & 0.00 \\
\hline & P-value: Food $=$ Cash $+B C C$ & 0.00 & 0.76 & 0.00 \\
\hline & $\mathrm{P}$-value: Cash\&food $=\mathrm{Cash}+\mathrm{BCC}$ & 0.00 & 0.07 & 0.00 \\
\hline & P-value: $\mathrm{Cash}=\mathrm{Cash}$ and food & 0.29 & 0.40 & 0.27 \\
\hline & P-value: Food $=$ Cash and food & 0.67 & 0.13 & 0.28 \\
\hline & P-value: Cash $=$ Food & 0.59 & 0.41 & 0.93 \\
\hline \multirow[t]{13}{*}{ South } & Cash & $\begin{array}{c}114.89 \\
(38.71)^{* * *}\end{array}$ & $\begin{array}{c}9.51 \\
(24.61)\end{array}$ & $\begin{array}{c}129.71 \\
(57.21)^{* *}\end{array}$ \\
\hline & Food & $\begin{array}{c}115.28 \\
(41.62)^{* * *}\end{array}$ & $\begin{array}{c}73.48 \\
(40.53)^{*}\end{array}$ & $\begin{array}{l}201.90 \\
(71.12)^{* * *}\end{array}$ \\
\hline & Cash and food & $\begin{array}{c}154.78 \\
(37.82)^{* * *}\end{array}$ & $\begin{array}{c}47.40 \\
(25.57)^{*}\end{array}$ & $\begin{array}{c}215.76 \\
(57.22)^{* * *}\end{array}$ \\
\hline & Food + BCC & $\begin{array}{c}280.89 \\
(35.77)^{* * *}\end{array}$ & $\begin{array}{c}44.06 \\
(24.69)^{*}\end{array}$ & $\begin{array}{c}337.14 \\
(51.19)^{* * *}\end{array}$ \\
\hline & $R^{2}$ & 0.05 & 0.09 & 0.07 \\
\hline & $N$ & 2,425 & 2,425 & 2,425 \\
\hline & Mean of Control & 1024.84 & 594.54 & 1619.37 \\
\hline & P-value: Cash $=$ Food + BCC & 0.00 & 0.16 & 0.00 \\
\hline & P-value: Food=Food + BCC & 0.00 & 0.47 & 0.05 \\
\hline & P-value: Cash\&food $=$ Food + BCC & 0.00 & 0.90 & 0.02 \\
\hline & P-value: Cash $=$ Cash and food & 0.34 & 0.14 & 0.15 \\
\hline & P-value: Food $=$ Cash and food & 0.38 & 0.53 & 0.85 \\
\hline & P-value: Cash=Food & 0.99 & 0.11 & 0.33 \\
\hline
\end{tabular}

Value, deflated to 2012 taka. Standard errors clustered at the village level. * $p<0.1 ; * * p<0.05 ; * * * p<0.01$. 
Table 2: Impact of treatment on value of total assets, loans, and net assets (in baseline Tk)

\begin{tabular}{|c|c|c|c|c|}
\hline & & $\begin{array}{l}\text { Total assets (including cash-in- } \\
\text { hand and savings) }\end{array}$ & Loans & Net assets \\
\hline \multirow[t]{13}{*}{ North } & בCash & $\begin{array}{c}11,263.57 \\
(2,428.70)^{* * *}\end{array}$ & $\begin{array}{l}-1,918.32 \\
(1,291.34)\end{array}$ & $\begin{array}{c}13,060.79 \\
(2,437.91)^{* * *}\end{array}$ \\
\hline & Food & $\begin{array}{c}9,410.14 \\
(2,493.08)^{* * *}\end{array}$ & $\begin{array}{c}-2,645.81 \\
(1,215.61)^{* *}\end{array}$ & $\begin{array}{c}12,099.32 \\
(2,393.27)^{* * *}\end{array}$ \\
\hline & Cash and food & $\begin{array}{c}7,159.09 \\
(2,740.46)^{* * *}\end{array}$ & $\begin{array}{l}-1,739.71 \\
(1,277.85)\end{array}$ & $\begin{array}{c}8,594.32 \\
(2,857.06)^{* * *}\end{array}$ \\
\hline & Cash + BCC & $\begin{array}{c}18,331.44 \\
(2,709.17)^{* * *}\end{array}$ & $\begin{array}{c}-2,786.31 \\
(1,198.95)^{* *}\end{array}$ & $\begin{array}{c}20,842.57 \\
(2,715.71)^{* * *}\end{array}$ \\
\hline & $R^{2}$ & 0.23 & 0.07 & 0.15 \\
\hline & $N$ & 2,395 & 2,395 & 2,395 \\
\hline & Mean of Control & 25834.41 & 9323.11 & 16511.30 \\
\hline & P-value: $\mathrm{Cash}=\mathrm{Cash}+\mathrm{BCC}$ & 0.02 & 0.38 & 0.01 \\
\hline & P-value: Food $=$ Cash $+B C C$ & 0.00 & 0.88 & 0.00 \\
\hline & P-value: Cash\&food=Cash $+\mathrm{BCC}$ & 0.00 & 0.29 & 0.00 \\
\hline & P-value: $\mathrm{Cash}=\mathrm{Cash}$ and food & 0.16 & 0.87 & 0.13 \\
\hline & P-value: Food $=$ Cash and food & 0.44 & 0.37 & 0.23 \\
\hline & P-value: Cash=Food & 0.49 & 0.48 & 0.71 \\
\hline \multirow[t]{13}{*}{ South } & בash & $\begin{array}{c}6,669.14 \\
(2,310.80)^{* * *}\end{array}$ & $\begin{array}{l}-1,481.15 \\
(1,382.37)\end{array}$ & $\begin{array}{c}7,377.88 \\
(2,662.91)^{* * *}\end{array}$ \\
\hline & Food & $\begin{array}{l}3,024.51 \\
(2,430.40)\end{array}$ & $\begin{array}{c}81.85 \\
(1,560.76)\end{array}$ & $\begin{array}{l}2,508.64 \\
(2,790.81)\end{array}$ \\
\hline & Cash and food & $\begin{array}{c}6,145.79 \\
(2,403.09)^{* *}\end{array}$ & $\begin{array}{c}-457.79 \\
(1,457.22)\end{array}$ & $\begin{array}{c}6,310.55 \\
(2,698.44)^{* *}\end{array}$ \\
\hline & Food + BCC & $\begin{array}{c}10,159.80 \\
(2,874.46)^{* * *}\end{array}$ & $\begin{array}{c}-2,751.72 \\
(1,046.66)^{* * *}\end{array}$ & $\begin{array}{c}12,767.43 \\
(3,108.60)^{* * *}\end{array}$ \\
\hline & $R^{2}$ & 0.25 & 0.08 & 0.16 \\
\hline & $N$ & 2,425 & 2,425 & 2,425 \\
\hline & Mean of Control & 29201.90 & 12724.78 & 16477.12 \\
\hline & P-value: Cash $=$ Food + BCC & 0.12 & 0.34 & 0.04 \\
\hline & P-value: Food=Food + BCC & 0.00 & 0.06 & 0.00 \\
\hline & P-value: Cash\&food=Food + BCC & 0.10 & 0.11 & 0.02 \\
\hline & P-value: $\mathrm{Cash}=\mathrm{Cash}$ and food & 0.77 & 0.54 & 0.63 \\
\hline & P-value: Food $=$ Cash and food & 0.10 & 0.77 & 0.10 \\
\hline & P-value: Cash=Food & 0.04 & 0.37 & 0.04 \\
\hline
\end{tabular}

Standard errors clustered at the village level. * $p<0.1 ; * * p<0.05 ; * * * p<0.01$. 
Table 3: Impact of treatment on household monthly income (in baseline Tk, based on last 7 days)

\begin{tabular}{|c|c|c|c|c|c|}
\hline & & $\mathrm{HH}$ total labor income & HH private transfers & HH public transfers & $\mathrm{HH}$ net income \\
\hline \multirow[t]{13}{*}{ North } & Cash & $\begin{array}{l}211.32 \\
(218.96)\end{array}$ & $\begin{array}{c}-9.49 \\
(53.66)\end{array}$ & $\begin{array}{c}16.80 \\
(15.35)\end{array}$ & $\begin{array}{l}214.63 \\
(219.45)\end{array}$ \\
\hline & Food & $\begin{array}{c}190.70 \\
(214.99)\end{array}$ & $\begin{array}{c}86.11 \\
(63.45)\end{array}$ & $\begin{array}{l}-14.11 \\
(12.91)\end{array}$ & $\begin{array}{l}262.04 \\
(228.42)\end{array}$ \\
\hline & Cash and food & $\begin{array}{c}70.23 \\
(191.44)\end{array}$ & $\begin{array}{c}46.38 \\
(71.28)\end{array}$ & $\begin{array}{c}0.13 \\
(14.24)\end{array}$ & $\begin{array}{c}112.97 \\
(201.52)\end{array}$ \\
\hline & $\mathrm{Cash}+\mathrm{BCC}$ & $\begin{array}{c}458.06 \\
(217.54)^{* *}\end{array}$ & $\begin{array}{l}126.94 \\
(78.28)\end{array}$ & $\begin{array}{l}31.23 \\
(25.37)\end{array}$ & $\begin{array}{c}614.97 \\
(237.82)^{* *}\end{array}$ \\
\hline & $R^{2}$ & 0.06 & 0.06 & 0.03 & 0.06 \\
\hline & $N$ & 2,395 & 2,395 & 2,395 & 2,395 \\
\hline & Mean of Control & 4103.03 & 304.35 & 99.58 & 4506.96 \\
\hline & P-value: $\mathrm{Cash}=\mathrm{Cash}+\mathrm{BCC}$ & 0.30 & 0.08 & 0.57 & 0.11 \\
\hline & P-value: Food $=$ Cash + BCC & 0.26 & 0.63 & 0.06 & 0.17 \\
\hline & P-value: Cash\&food $=$ Cash $+B C C$ & 0.07 & 0.37 & 0.21 & 0.03 \\
\hline & P-value: $\mathrm{Cash}=\mathrm{Cash}$ and food & 0.51 & 0.43 & 0.24 & 0.64 \\
\hline & P-value: Food $=$ Cash and food & 0.57 & 0.61 & 0.21 & 0.51 \\
\hline & P-value: Cash=Food & 0.93 & 0.13 & 0.02 & 0.84 \\
\hline \multirow[t]{13}{*}{ South } & Cash & $\begin{array}{c}494.42 \\
(232.78)^{* *}\end{array}$ & $\begin{array}{c}-203.78 \\
(114.77)^{*}\end{array}$ & $\begin{array}{l}-25.24 \\
(21.41)\end{array}$ & $\begin{array}{c}227.24 \\
(235.17)\end{array}$ \\
\hline & Food & $\begin{array}{c}44.37 \\
(223.52)\end{array}$ & $\begin{array}{c}-185.74 \\
(101.78)^{*}\end{array}$ & $\begin{array}{c}-40.72 \\
(20.40)^{* *}\end{array}$ & $\begin{array}{l}-189.49 \\
(220.18)\end{array}$ \\
\hline & Cash and food & $\begin{array}{c}136.61 \\
(263.01)\end{array}$ & $\begin{array}{l}-141.48 \\
(102.38)\end{array}$ & $\begin{array}{c}-42.94 \\
(20.08)^{* *}\end{array}$ & $\begin{array}{c}-49.49 \\
(257.04)\end{array}$ \\
\hline & Food + BCC & $\begin{array}{c}574.05 \\
(235.96)^{* *}\end{array}$ & $\begin{array}{l}-146.17 \\
(112.82)\end{array}$ & $\begin{array}{l}-34.76 \\
(23.94)\end{array}$ & $\begin{array}{c}400.47 \\
(225.74)^{*}\end{array}$ \\
\hline & $R^{2}$ & 0.15 & 0.25 & 0.01 & 0.11 \\
\hline & $N$ & 2,425 & 2,425 & 2,425 & 2,425 \\
\hline & Mean of Control & 4965.43 & 735.70 & 143.63 & 5844.76 \\
\hline & P-value: $\mathrm{Cash}=$ Food $+\mathrm{BCC}$ & 0.75 & 0.59 & 0.62 & 0.44 \\
\hline & P-value: Food=Food + BCC & 0.03 & 0.69 & 0.74 & 0.01 \\
\hline & P-value: Cash\&food=Food + BCC & 0.11 & 0.96 & 0.64 & 0.07 \\
\hline & P-value: $\mathrm{Cash}=\mathrm{Cash}$ and food & 0.19 & 0.52 & 0.20 & 0.28 \\
\hline & P-value: Food=Cash and food & 0.73 & 0.59 & 0.86 & 0.57 \\
\hline & P-value: Cash=Food & 0.06 & 0.85 & 0.28 & 0.06 \\
\hline
\end{tabular}

Standard errors clustered at the village level. ${ }^{*} p<0.1 ;{ }^{* *} p<0.05 ; * * * p<0.01$. 
Table 4: Impact of treatment on household monthly labor income (in baseline Tk, based on last 7 days)

\begin{tabular}{|c|c|c|c|c|c|c|}
\hline & & HH total labor income & $\begin{array}{l}\mathrm{HH} \text { agricultural wage } \\
\text { income }\end{array}$ & $\begin{array}{l}\text { HH non-agricultural } \\
\text { wage income }\end{array}$ & $\begin{array}{l}\text { HH own farm } \\
\text { labor income }\end{array}$ & $\begin{array}{l}\text { HH non-farm self- } \\
\text { employment income }\end{array}$ \\
\hline \multirow[t]{11}{*}{ North } & "Cash & $\begin{array}{c}211.32 \\
(218.96)\end{array}$ & $\begin{array}{c}-282.10 \\
(164.86)^{*}\end{array}$ & $\begin{array}{c}69.70 \\
(147.21)\end{array}$ & $\begin{array}{c}203.16 \\
(103.08)^{* *}\end{array}$ & $\begin{array}{c}253.65 \\
(139.64)^{*}\end{array}$ \\
\hline & Food & $\begin{array}{l}190.70 \\
(214.99)\end{array}$ & $\begin{array}{c}-334.41 \\
(159.48)^{* *}\end{array}$ & $\begin{array}{c}230.85 \\
(126.39)^{*}\end{array}$ & $\begin{array}{c}163.95 \\
(104.37)\end{array}$ & $\begin{array}{c}149.82 \\
(154.30)\end{array}$ \\
\hline & Cash and food & $\begin{array}{c}70.23 \\
(191.44)\end{array}$ & $\begin{array}{l}-224.67 \\
(170.67)\end{array}$ & $\begin{array}{c}-23.51 \\
(131.19)\end{array}$ & $\begin{array}{c}187.58 \\
(98.10)^{*}\end{array}$ & $\begin{array}{c}147.55 \\
(131.96)\end{array}$ \\
\hline & $R^{2}$ & 0.06 & 0.09 & 0.05 & 0.13 & 0.19 \\
\hline & $N$ & 2,395 & 2,395 & 2,395 & 2,395 & 2,395 \\
\hline & Mean of Control & 4103.03 & 1315.04 & 731.13 & 731.05 & 1325.80 \\
\hline & P-value: $\mathrm{Cash}=\mathrm{Cash}+\mathrm{BCC}$ & 0.30 & 0.90 & 0.52 & 0.06 & 0.45 \\
\hline & P-value: Food $=$ Cash $+B C C$ & 0.26 & 0.80 & 0.05 & 0.03 & 0.19 \\
\hline & P-value: Cash\&food $=\mathrm{Cash}+\mathrm{BCC}$ & 0.07 & 0.61 & 0.97 & 0.04 & 0.14 \\
\hline & P-value: Cash=Cash and food & 0.51 & 0.69 & 0.54 & 0.88 & 0.42 \\
\hline & P-value: Cash=Food & 0.93 & 0.69 & 0.28 & 0.72 & 0.50 \\
\hline \multirow[t]{11}{*}{ South } & Cash & $\begin{array}{c}494.42 \\
(232.78)^{* *}\end{array}$ & $\begin{array}{c}312.42 \\
(144.46)^{* *}\end{array}$ & $\begin{array}{c}-76.03 \\
(176.76)\end{array}$ & $\begin{array}{c}7.22 \\
(165.67)\end{array}$ & $\begin{array}{c}124.25 \\
(191.00)\end{array}$ \\
\hline & Food & $\begin{array}{c}44.37 \\
(223.52)\end{array}$ & $\begin{array}{c}62.11 \\
(111.49)\end{array}$ & $\begin{array}{c}-47.18 \\
(196.32)\end{array}$ & $\begin{array}{c}-24.50 \\
(172.40)\end{array}$ & $\begin{array}{c}-35.55 \\
(167.99)\end{array}$ \\
\hline & Cash and food & $\begin{array}{l}136.61 \\
(263.01)\end{array}$ & $\begin{array}{c}3.40 \\
(114.89)\end{array}$ & $\begin{array}{l}-17.02 \\
(197.02)\end{array}$ & $\begin{array}{l}-35.56 \\
(174.57)\end{array}$ & $\begin{array}{c}70.82 \\
(180.61)\end{array}$ \\
\hline & Food + BCC & $\begin{array}{c}574.05 \\
(235.96)^{* *}\end{array}$ & $\begin{array}{c}161.30 \\
(130.72)\end{array}$ & $\begin{array}{c}35.54 \\
(193.50)\end{array}$ & $\begin{array}{c}173.12 \\
(167.50)\end{array}$ & $\begin{array}{l}128.24 \\
(163.85)\end{array}$ \\
\hline & $R^{2}$ & 0.15 & 0.05 & 0.08 & 0.23 & 0.25 \\
\hline & $N$ & 2,425 & 2,425 & 2,425 & 2,425 & 2,425 \\
\hline & Mean of Control & 4965.43 & 578.57 & 1540.57 & 1379.45 & 1466.84 \\
\hline & P-value: $\mathrm{Cash}=\mathrm{Food}+\mathrm{BCC}$ & 0.75 & 0.34 & 0.51 & 0.25 & 0.98 \\
\hline & P-value: Food=Food + BCC & 0.03 & 0.45 & 0.66 & 0.19 & 0.36 \\
\hline & P-value: Cash\&food=Food + BCC & 0.11 & 0.24 & 0.78 & 0.17 & 0.77 \\
\hline & P-value: $\mathrm{Cash}=\mathrm{Cash}$ and food & 0.19 & 0.04 & 0.73 & 0.78 & 0.80 \\
\hline
\end{tabular}

Standard errors clustered at the village level. * $p<0.1 ; * * p<0.05 ; * * * p<0.01$. 
Table 5: Impact of treatment on monthly private transfers received by household (in baseline Tk, based on last 12 months)

\begin{tabular}{|c|c|c|c|c|c|c|}
\hline & & $\begin{array}{c}\text { Whether received any } \\
\text { private transfer }\end{array}$ & Total private transfers & $\begin{array}{c}\text { International } \\
\text { remittances from } \\
\text { relatives }\end{array}$ & $\begin{array}{c}\text { Domestic } \\
\text { remittances from } \\
\text { relatives }\end{array}$ & $\begin{array}{c}\text { Other private } \\
\text { transfers (charity } \\
\text { or dowry) }\end{array}$ \\
\hline \multirow[t]{13}{*}{ North } & בCash & $\begin{array}{l}-0.01 \\
(0.04)\end{array}$ & $\begin{array}{l}-9.49 \\
(53.66)\end{array}$ & $\begin{array}{l}24.62 \\
(15.18)\end{array}$ & $\begin{array}{l}-42.79 \\
(47.96)\end{array}$ & $\begin{array}{c}4.37 \\
(17.08)\end{array}$ \\
\hline & Food & $\begin{array}{c}0.01 \\
(0.05)\end{array}$ & $\begin{array}{c}86.11 \\
(63.45)\end{array}$ & $\begin{array}{c}6.94 \\
(7.31)\end{array}$ & $\begin{array}{c}66.97 \\
(59.18)\end{array}$ & $\begin{array}{c}-0.28 \\
(15.08)\end{array}$ \\
\hline & Cash and food & $\begin{array}{l}-0.03 \\
(0.05)\end{array}$ & $\begin{array}{l}46.38 \\
(71.28)\end{array}$ & $\begin{array}{l}-4.29 \\
(3.43)\end{array}$ & $\begin{array}{l}39.44 \\
(67.07)\end{array}$ & $\begin{array}{c}6.90 \\
(15.63)\end{array}$ \\
\hline & $\mathrm{Cash}+\mathrm{BCC}$ & $\begin{array}{l}-0.04 \\
(0.04)\end{array}$ & $\begin{array}{l}126.94 \\
(78.28)\end{array}$ & $\begin{array}{l}36.39 \\
(22.73)\end{array}$ & $\begin{array}{l}95.05 \\
(72.74)\end{array}$ & $\begin{array}{l}-7.19 \\
(12.65)\end{array}$ \\
\hline & $R^{2}$ & 0.02 & 0.06 & 0.02 & 0.07 & 0.00 \\
\hline & $N$ & 2,395 & 2,395 & 2,395 & 2,395 & 2,395 \\
\hline & Mean of Control & 0.53 & 304.35 & 1.52 & 287.01 & 15.82 \\
\hline & P-value: $\mathrm{Cash}=\mathrm{Cash}+\mathrm{BCC}$ & 0.43 & 0.08 & 0.67 & 0.06 & 0.36 \\
\hline & P-value: Food $=$ Cash + BCC & 0.28 & 0.63 & 0.21 & 0.73 & 0.48 \\
\hline & P-value: Cash\&food $=$ Cash $+B C C$ & 0.78 & 0.37 & 0.10 & 0.52 & 0.18 \\
\hline & P-value: $\mathrm{Cash}=\mathrm{Cash}$ and food & 0.65 & 0.43 & 0.06 & 0.22 & 0.87 \\
\hline & P-value: Food $=$ Cash and food & 0.46 & 0.61 & 0.16 & 0.72 & 0.58 \\
\hline & P-value: Cash=Food & 0.75 & 0.13 & 0.29 & 0.07 & 0.76 \\
\hline \multirow[t]{13}{*}{ "South } & Cash & $\begin{array}{c}-0.11 \\
(0.05)^{* *}\end{array}$ & $\begin{array}{l}-203.78 \\
(114.77)^{*}\end{array}$ & $\begin{array}{c}2.92 \\
(13.82)\end{array}$ & $\begin{array}{c}-206.49 \\
(116.05)^{*}\end{array}$ & $\begin{array}{c}0.66 \\
(5.89)\end{array}$ \\
\hline & Food & $\begin{array}{l}-0.08 \\
(0.05)\end{array}$ & $\begin{array}{l}-185.74 \\
(101.78)^{*}\end{array}$ & $\begin{array}{l}-7.13 \\
(14.52)\end{array}$ & $\begin{array}{l}-180.35 \\
(104.39)^{*}\end{array}$ & $\begin{array}{l}-0.40 \\
(5.16)\end{array}$ \\
\hline & Cash and food & $\begin{array}{c}-0.09 \\
(0.05)^{*}\end{array}$ & $\begin{array}{l}-141.48 \\
(102.38)\end{array}$ & $\begin{array}{c}35.82 \\
(31.65)\end{array}$ & $\begin{array}{c}-185.32 \\
(102.56)^{*}\end{array}$ & $\begin{array}{c}10.47 \\
(10.22)\end{array}$ \\
\hline & Food + BCC & $\begin{array}{l}-0.08 \\
(0.05)\end{array}$ & $\begin{array}{l}-146.17 \\
(112.82)\end{array}$ & $\begin{array}{c}4.46 \\
(11.19) \\
\end{array}$ & $\begin{array}{l}-166.23 \\
(113.37) \\
\end{array}$ & $\begin{array}{l}13.48 \\
(8.46)\end{array}$ \\
\hline & $R^{2}$ & 0.06 & 0.25 & 0.62 & 0.19 & 0.00 \\
\hline & $N$ & 2,425 & 2,425 & 2,425 & 2,425 & 2,425 \\
\hline & Mean of Control & 0.54 & 735.70 & 16.94 & 711.42 & 7.34 \\
\hline & P-value: $\mathrm{Cash}=\mathrm{Food}+\mathrm{BCC}$ & 0.52 & 0.59 & 0.90 & 0.70 & 0.10 \\
\hline & P-value: Food=Food + BCC & 0.99 & 0.69 & 0.39 & 0.88 & 0.05 \\
\hline & P-value: Cash\&food=Food + BCC & 0.72 & 0.96 & 0.32 & 0.84 & 0.79 \\
\hline & P-value: $\mathrm{Cash}=\mathrm{Cash}$ and food & 0.76 & 0.52 & 0.31 & 0.82 & 0.31 \\
\hline & P-value: Food $=$ Cash and food & 0.73 & 0.59 & 0.19 & 0.95 & 0.23 \\
\hline & P-value: Cash=Food & 0.51 & 0.85 & 0.52 & 0.79 & 0.78 \\
\hline
\end{tabular}

Standard errors clustered at the village level. * $p<0.1 ; * * p<0.05 ; * * * p<0.01$. 
Table 6: Impact of treatment on value of household asset categories (in baseline Tk)

\begin{tabular}{|c|c|c|c|c|c|c|}
\hline & & Livestock & Poultry & $\begin{array}{l}\text { Productive non-animal } \\
\text { assets }\end{array}$ & Consumer durables & Cash in hand \\
\hline \multirow[t]{13}{*}{ North } & Cash & $\begin{array}{c}3,004.65 \\
(1,060.97)^{* * *}\end{array}$ & $\begin{array}{c}82.39 \\
(40.10)^{* *}\end{array}$ & $\begin{array}{l}-340.93 \\
(446.88)\end{array}$ & $\begin{array}{c}1,239.11 \\
(521.14)^{* *}\end{array}$ & $\begin{array}{c}415.73 \\
(87.24)^{* * *}\end{array}$ \\
\hline & Food & $\begin{array}{c}2,452.83 \\
(976.50)^{* *}\end{array}$ & $\begin{array}{c}64.31 \\
(47.04)\end{array}$ & $\begin{array}{l}382.06 \\
(472.45)\end{array}$ & $\begin{array}{c}701.60 \\
(425.54)\end{array}$ & $\begin{array}{c}285.09 \\
(86.79)^{* * *}\end{array}$ \\
\hline & Cash and food & $\begin{array}{c}2,121.90 \\
(1,019.01)^{* *}\end{array}$ & $\begin{array}{c}33.75 \\
(41.32)\end{array}$ & $\begin{array}{l}-394.33 \\
(338.74)\end{array}$ & $\begin{array}{l}1,103.99 \\
(628.78)^{*}\end{array}$ & $\begin{array}{c}283.84 \\
(86.34)^{* * *}\end{array}$ \\
\hline & Cash + BCC & $\begin{array}{c}4,164.32 \\
(1,085.64)^{* * *}\end{array}$ & $\begin{array}{c}180.00 \\
(40.53)^{* * *}\end{array}$ & $\begin{array}{c}560.92 \\
(443.11)\end{array}$ & $\begin{array}{c}2,326.35 \\
(590.52)^{* * *}\end{array}$ & $\begin{array}{c}461.49 \\
(92.31)^{* * *}\end{array}$ \\
\hline & $R^{2}$ & 0.09 & 0.07 & 0.19 & 0.22 & 0.01 \\
\hline & $N$ & 2,395 & 2,395 & 2,395 & 2,395 & 2,395 \\
\hline & Mean of Control & 8500.03 & 434.44 & 2716.59 & 6645.18 & 291.09 \\
\hline & P-value: $\mathrm{Cash}=\mathrm{Cash}+\mathrm{BCC}$ & 0.28 & 0.02 & 0.07 & 0.09 & 0.70 \\
\hline & P-value: Food $=$ Cash $+\mathrm{BCC}$ & 0.09 & 0.02 & 0.73 & 0.01 & 0.14 \\
\hline & P-value: Cash\&food $=\mathrm{Cash}+\mathrm{BCC}$ & 0.05 & 0.00 & 0.02 & 0.10 & 0.13 \\
\hline & P-value: $\mathrm{Cash}=\mathrm{Cash}$ and food & 0.39 & 0.25 & 0.89 & 0.84 & 0.25 \\
\hline & P-value: Food=Cash and food & 0.72 & 0.54 & 0.07 & 0.52 & 0.99 \\
\hline & P-value: Cash=Food & 0.57 & 0.71 & 0.18 & 0.29 & 0.26 \\
\hline \multirow[t]{13}{*}{ South } & Cash & $\begin{array}{c}864.90 \\
(1,439.71)\end{array}$ & $\begin{array}{c}18.61 \\
(203.50)\end{array}$ & $\begin{array}{c}216.71 \\
(613.45)\end{array}$ & $\begin{array}{c}1,188.90 \\
(905.74)\end{array}$ & $\begin{array}{c}440.79 \\
(103.00)^{* * *}\end{array}$ \\
\hline & Food & $\begin{array}{l}-1,034.73 \\
(1,512.54)\end{array}$ & $\begin{array}{l}-165.55 \\
(200.65)\end{array}$ & $\begin{array}{c}91.64 \\
(635.37)\end{array}$ & $\begin{array}{c}1,155.51 \\
(924.08)\end{array}$ & $\begin{array}{c}383.59 \\
(143.64)^{* * *}\end{array}$ \\
\hline & Cash and food & $\begin{array}{c}673.00 \\
(1,507.96)\end{array}$ & $\begin{array}{l}-59.10 \\
(211.40)\end{array}$ & $\begin{array}{c}790.78 \\
(755.79)\end{array}$ & $\begin{array}{c}1,917.98 \\
(934.05)^{* *}\end{array}$ & $\begin{array}{c}318.27 \\
(91.19)^{* * *}\end{array}$ \\
\hline & Food + BCC & $\begin{array}{r}1,595.33 \\
(1,637.33) \\
\end{array}$ & $\begin{array}{c}204.90 \\
(235.65)\end{array}$ & $\begin{array}{c}1,356.66 \\
(881.80)\end{array}$ & $\begin{array}{c}2,324.98 \\
(1,056.69)^{* *}\end{array}$ & $\begin{array}{c}452.65 \\
(103.83)^{* * *}\end{array}$ \\
\hline & $R^{2}$ & 0.16 & 0.09 & 0.16 & 0.28 & 0.02 \\
\hline & $N$ & 2,425 & 2,425 & 2,425 & 2,425 & 2,425 \\
\hline & Mean of Control & 8916.36 & 1129.76 & 3544.28 & 12053.53 & 499.08 \\
\hline & P-value: Cash=Food + BCC & 0.51 & 0.15 & 0.18 & 0.23 & 0.93 \\
\hline & P-value: Food=Food + BCC & 0.02 & 0.01 & 0.15 & 0.22 & 0.67 \\
\hline & P-value: Cash\&food=Food + BCC & 0.44 & 0.15 & 0.56 & 0.67 & 0.27 \\
\hline & P-value: Cash=Cash and food & 0.84 & 0.50 & 0.42 & 0.37 & 0.32 \\
\hline & P-value: Food $=$ Cash and food & 0.10 & 0.34 & 0.34 & 0.36 & 0.68 \\
\hline & P-value: Cash=Food & 0.04 & 0.04 & 0.83 & 0.97 & 0.73 \\
\hline
\end{tabular}

Standard errors clustered at the village level. * $p<0.1 ; * * p<0.05 ; * * * p<0.01$. 
Table 7: Impact of treatment on household leased land (area in decimals)

\begin{tabular}{|c|c|c|c|c|}
\hline & & Total land leased & Land leased using cash & Land leased through share cropping \\
\hline \multirow[t]{12}{*}{ North } & Cash & $\begin{array}{c}2.05 \\
(1.81)\end{array}$ & $\begin{array}{c}0.26 \\
(0.52)\end{array}$ & $\begin{array}{c}1.70 \\
(1.76)\end{array}$ \\
\hline & Food & $\begin{array}{l}-0.31 \\
(1.79)\end{array}$ & $\begin{array}{c}-0.64 \\
(0.38)^{*}\end{array}$ & $\begin{array}{c}0.56 \\
(1.80)\end{array}$ \\
\hline & Cash and food & $\begin{array}{c}3.66 \\
(1.96)^{*}\end{array}$ & $\begin{array}{c}1.04 \\
(1.35)\end{array}$ & $\begin{array}{c}2.49 \\
(1.61)\end{array}$ \\
\hline & $\mathrm{Cash}+\mathrm{BCC}$ & $\begin{array}{c}6.97 \\
(2.30)^{* * *}\end{array}$ & $\begin{array}{c}1.10 \\
(0.77)\end{array}$ & $\begin{array}{c}6.04 \\
(2.18)^{* * *}\end{array}$ \\
\hline & $R^{2}$ & 0.17 & 0.01 & 0.17 \\
\hline & $N$ & 2,395 & 2,395 & 2,395 \\
\hline & Mean of Control & 13.69 & 1.07 & 12.62 \\
\hline & P-value: $\mathrm{Cash}=\mathrm{Cash}+\mathrm{BCC}$ & 0.03 & 0.30 & 0.04 \\
\hline & P-value: Food $=$ Cash $+B C C$ & 0.00 & 0.02 & 0.01 \\
\hline & P-value: Cash\&food=Cash $+\mathrm{BCC}$ & 0.16 & 0.97 & 0.07 \\
\hline & P-value: $\mathrm{Cash}=\mathrm{Cash}$ and food & 0.40 & 0.57 & 0.60 \\
\hline & P-value: Food $=$ Cash and food & 0.03 & 0.21 & 0.22 \\
\hline \multirow[t]{12}{*}{ South } & Cash & $\begin{array}{c}0.50 \\
(5.04)\end{array}$ & $\begin{array}{c}1.98 \\
(3.38)\end{array}$ & $\begin{array}{l}-2.58 \\
(3.23)\end{array}$ \\
\hline & Food & $\begin{array}{l}-7.00 \\
(5.23)\end{array}$ & $\begin{array}{l}-3.13 \\
(3.33)\end{array}$ & $\begin{array}{l}-4.39 \\
(3.49)\end{array}$ \\
\hline & Cash and food & $\begin{array}{l}-1.11 \\
(5.04)\end{array}$ & $\begin{array}{l}-0.02 \\
(3.23)\end{array}$ & $\begin{array}{l}-2.26 \\
(3.53)\end{array}$ \\
\hline & Food + BCC & $\begin{array}{c}4.54 \\
(6.44) \\
\end{array}$ & $\begin{array}{c}3.15 \\
(4.59) \\
\end{array}$ & $\begin{array}{c}0.06 \\
(3.74) \\
\end{array}$ \\
\hline & $R^{2}$ & 0.21 & 0.13 & 0.11 \\
\hline & $N$ & 2,425 & 2,425 & 2,425 \\
\hline & Mean of Control & 31.99 & 16.02 & 15.98 \\
\hline & P-value: $\mathrm{Cash}=\mathrm{Food}+\mathrm{BCC}$ & 0.45 & 0.78 & 0.40 \\
\hline & P-value: Food=Food + BCC & 0.04 & 0.15 & 0.20 \\
\hline & P-value: Cash\&food=Food + BCC & 0.30 & 0.46 & 0.51 \\
\hline & P-value: $\mathrm{Cash}=\mathrm{Cash}$ and food & 0.69 & 0.51 & 0.91 \\
\hline & P-value: Food=Cash and food & 0.14 & 0.28 & 0.51 \\
\hline
\end{tabular}

Standard errors clustered at the village level. ${ }^{*} p<0.1 ; * * p<0.05 ; * * * p<0.01$. 
Table 8: Impact of treatment on household cultivating improved rice (HYV/hybrid vs. LIV/local) varieties or wheat

\begin{tabular}{|c|c|c|}
\hline & & Cultivating improved rice or wheat \\
\hline \multirow[t]{13}{*}{ North } & Cash & $\begin{array}{c}0.07 \\
(0.04)^{*}\end{array}$ \\
\hline & Food & $\begin{array}{c}0.04 \\
(0.04)\end{array}$ \\
\hline & Cash and food & $\begin{array}{l}-0.00 \\
(0.04)\end{array}$ \\
\hline & Cash + BCC & $\begin{array}{c}0.14 \\
(0.04)^{* * *}\end{array}$ \\
\hline & $R^{2}$ & 0.18 \\
\hline & $N$ & 2,395 \\
\hline & Mean of Control & 0.38 \\
\hline & P-value: $\mathrm{Cash}=\mathrm{Cash}+\mathrm{BCC}$ & 0.09 \\
\hline & P-value: Food $=$ Cash + BCC & 0.02 \\
\hline & P-value: Cash\&food=Cash $+\mathrm{BCC}$ & 0.00 \\
\hline & P-value: Cash $=$ Cash and food & 0.05 \\
\hline & P-value: Food $=$ Cash and food & 0.19 \\
\hline & P-value: Cash=Food & 0.51 \\
\hline \multirow[t]{13}{*}{ South } & Cash & $\begin{array}{c}0.06 \\
(0.03)^{* *}\end{array}$ \\
\hline & Food & $\begin{array}{l}-0.01 \\
(0.03)\end{array}$ \\
\hline & Cash and food & $\begin{array}{c}0.02 \\
(0.03)\end{array}$ \\
\hline & Food + BCC & $\begin{array}{c}0.04 \\
(0.03)\end{array}$ \\
\hline & $R^{2}$ & 0.12 \\
\hline & $N$ & 2,425 \\
\hline & Mean of Control & 0.17 \\
\hline & P-value: Cash=Food + BCC & 0.58 \\
\hline & P-value: Food=Food + BCC & 0.11 \\
\hline & P-value: Cash\&food=Food + BCC & 0.46 \\
\hline & P-value: Cash $=$ Cash and food & 0.15 \\
\hline & P-value: Food $=$ Cash and food & 0.34 \\
\hline & P-value: Cash=Food & 0.02 \\
\hline
\end{tabular}

Standard errors clustered at the village level. * $p<0.1 ; * * p<0.05 ; * * * p<0.01$. 


\section{Appendices}

\section{Appendix 1: Impacts on household diet}

As Table A3 shows, in the North, estimates reveal that all treatments significantly improve nearly all household diet indicators assessed. Cash significantly increases per capita daily caloric intake by about 75 calories (a $4 \%$ increase relative to the control), increases FCS by nearly 7 (a $15 \%$ increase), and reduces the prevalence of low FCS by 17 percentage points (a $65 \%$ decline), but has no significant impact on food poverty. Food has similar or even larger impacts on diet indicators than cash, with significant differences from cash in terms of impacts on caloric intake (increase of 143 calories), on FCS (increase of 9), and prevalence of low FCS (decline of 21 percentage points). Impacts of the combination of cash and food are not significantly different from the impacts of cash.

However, the impacts on diet indicators of Cash+BCC in the North are significantly larger than the impacts of any other treatment, and by a substantial magnitude. Cash+BCC significantly increases per capita daily caloric intake by about 280 calories (a 15\% increase relative to the control), increases FCS by 23 (a 52\% increase), reduces the prevalence of low FCS by 25 percentage points (a nearly 100\% decline), and additionally decreases prevalence of food poverty by 26 percentage points (a $33 \%$ decline).

In the South, where the control group's dietary indicators are considerably better on average than in the North, effects are more modest. Cash significantly increases FCS by about 3 (a $5 \%$ increase) but has no significant impact on caloric intake, prevalence of food poverty, or prevalence of low FCS. The food arm has similar or slightly larger impacts on diet indicators than cash, with a significant difference from cash in terms of the impact on FCS (increase of about 5), as well as causing a significant reduction in prevalence of low FCS (decline of 4 percentage points). The combination of cash and food has similar impacts to cash, but with a significantly higher impact on FCS (increase of about 5).

Like Cash $+\mathrm{BCC}$ in the North, Food $+\mathrm{BCC}$ in the South has significantly larger impacts on diet indicators than any other treatment, by a substantial magnitude. Food $+\mathrm{BCC}$ significantly increases per capita daily caloric intake by about 140 calories (a 7\% increase), decreases prevalence of food poverty by 15 percentage points (a 20\% decline), increases FCS by nearly 13 (a 23\% increase), and reduces the prevalence of low FCS by about 5 percentage points (an $83 \%$ decline). 


\section{Appendix tables}

Table A1: Impact of treatment on attrition, by region

\begin{tabular}{lcc}
\hline & North & South \\
\hline \hline Cash & -0.02 & -0.02 \\
& $(0.01)$ & $(0.01)$ \\
Food & -0.02 & -0.01 \\
& $(0.01)$ & $(0.01)$ \\
Cash and food & -0.02 & -0.00 \\
& $(0.01)$ & $(0.01)$ \\
Cash + BCC & -0.00 & -0.01 \\
& $(0.02)$ & $(0.01)$ \\
\hline$R^{2}$ & 0.00 & 0.00 \\
$N$ & 2,500 & 2,500 \\
\hline Mean of Control & 0.05 & 0.04 \\
P-value: Cash=Cash+BCC & 0.32 & 0.44 \\
P-value: Food=Cash+BCC & 0.31 & 0.58 \\
P-value: Cash and food=Cash+BCC & 0.20 & 0.59 \\
P-value: Cash=Cash and food & 0.75 & 0.12 \\
P-value: Food=Cash and food & 0.74 & 0.21 \\
P-value: Cash=Food & 1.00 & 0.82 \\
\hline
\end{tabular}

Standard errors clustered at the village level. * $p<0.1 * * p<0.05 ; * * * p<0.01$ 
Table A2: Baseline summary statistics in non-attrited estimation sample by intervention arm

\begin{tabular}{|c|c|c|c|c|c|c|c|c|c|}
\hline \multirow[b]{2}{*}{ NORTH } & \multicolumn{5}{|c|}{ Means } & \multicolumn{4}{|c|}{ P-val of diff. } \\
\hline & Cash & Food & Cash\&Food & $\mathrm{Cash}+\mathrm{BCC}$ & Control & $\begin{array}{l}\text { Cash - } \\
\text { Control }\end{array}$ & $\begin{array}{l}\text { Food - } \\
\text { Control }\end{array}$ & $\begin{array}{l}\text { Cash\&Food } \\
\text { - Control }\end{array}$ & $\begin{array}{l}\text { Cash+BCC } \\
\text { - Control }\end{array}$ \\
\hline Household size & 4.69 & 4.68 & 4.80 & 4.82 & 4.83 & 0.16 & 0.12 & 0.75 & 0.94 \\
\hline Number of children age $0-4$ & 1.23 & 1.23 & 1.30 & 1.27 & 1.29 & 0.07 & 0.09 & 0.74 & 0.55 \\
\hline Number of children age 5-14 & 1.04 & 1.08 & 1.08 & 1.10 & 0.99 & 0.42 & 0.15 & 0.20 & 0.19 \\
\hline Head's years schooling & 1.49 & 1.23 & 1.28 & 1.43 & 1.43 & 0.78 & 0.26 & 0.37 & 1.00 \\
\hline Main female's years schooling & 2.30 & 2.14 & 2.03 & 2.10 & 2.37 & 0.76 & 0.30 & 0.12 & 0.25 \\
\hline Female-headed household & 0.06 & 0.08 & 0.08 & 0.08 & 0.06 & 0.95 & 0.28 & 0.40 & 0.43 \\
\hline Total owned land in decimals & 14.11 & 14.72 & 12.44 & 13.76 & 15.45 & 0.65 & 0.81 & 0.28 & 0.53 \\
\hline Food consumption per capita & 875.73 & 869.69 & 808.54 & 898.40 & 850.68 & 0.51 & 0.61 & 0.21 & 0.54 \\
\hline Non-food consumption per capita & 493.75 & 503.92 & 465.09 & 464.61 & 480.41 & 0.67 & 0.41 & 0.55 & 0.56 \\
\hline Total consumption per capita & $1,369.48$ & $1,373.61$ & $1,273.63$ & $1,363.01$ & $1,331.09$ & 0.55 & 0.49 & 0.29 & 0.73 \\
\hline Total assets & $21,412.32$ & $23,041.52$ & $19,488.36$ & $19,883.80$ & $22,674.94$ & 0.66 & 0.91 & 0.25 & 0.28 \\
\hline Loans & $7,361.03$ & $8,066.85$ & $6,838.00$ & $6,718.13$ & $7,732.28$ & 0.70 & 0.79 & 0.36 & 0.27 \\
\hline Net assets & $14,051.30$ & $14,974.66$ & $12,650.36$ & $13,165.67$ & $14,942.66$ & 0.74 & 0.99 & 0.39 & 0.47 \\
\hline Household total labor income & $4,356.93$ & $4,349.26$ & $4,658.81$ & $4,530.10$ & $4,435.15$ & 0.75 & 0.75 & 0.43 & 0.67 \\
\hline Household private transfers & 276.67 & 320.05 & 243.41 & 275.95 & 310.46 & 0.51 & 0.87 & 0.16 & 0.51 \\
\hline Household public transfers & 0.14 & 2.59 & 0.00 & 6.49 & 8.37 & 0.00 & 0.07 & 0.00 & 0.63 \\
\hline Household net income & $4,633.73$ & $4,671.89$ & $4,902.22$ & $4,812.54$ & $4,753.99$ & 0.65 & 0.76 & 0.61 & 0.80 \\
\hline SOUTH & Cash & Food & Cash\&Food & Food + BCC & Control & $\begin{array}{l}\text { Cash - } \\
\text { Control }\end{array}$ & $\begin{array}{l}\text { Food - } \\
\text { Control }\end{array}$ & $\begin{array}{c}\text { Cash\&Food } \\
\text { - Control }\end{array}$ & $\begin{array}{c}\text { Food+BCC } \\
\text { - Control }\end{array}$ \\
\hline Household size & 5.25 & 5.22 & 5.06 & 5.20 & 5.30 & 0.66 & 0.57 & 0.06 & 0.49 \\
\hline Number of children age $0-4$ & 1.29 & 1.27 & 1.31 & 1.25 & 1.28 & 0.83 & 0.71 & 0.52 & 0.39 \\
\hline Number of children age 5-14 & 1.31 & 1.39 & 1.17 & 1.16 & 1.30 & 0.87 & 0.37 & 0.19 & 0.19 \\
\hline Head's years schooling & 1.78 & 1.83 & 1.97 & 2.26 & 2.05 & 0.35 & 0.40 & 0.77 & 0.48 \\
\hline Main female's years schooling & 2.52 & 2.49 & 2.82 & 3.01 & 3.08 & 0.08 & 0.02 & 0.40 & 0.84 \\
\hline Female-headed household & 0.09 & 0.13 & 0.10 & 0.13 & 0.12 & 0.37 & 0.72 & 0.62 & 0.67 \\
\hline Total owned land in decimals & 17.60 & 18.22 & 27.17 & 22.82 & 27.24 & 0.01 & 0.01 & 0.99 & 0.34 \\
\hline Food consumption per capita & $1,029.21$ & $1,105.16$ & $1,164.27$ & $1,021.03$ & $1,179.78$ & 0.22 & 0.58 & 0.91 & 0.20 \\
\hline Non-food consumption per capita & 540.90 & 593.85 & 610.97 & 568.22 & 556.84 & 0.52 & 0.17 & 0.07 & 0.67 \\
\hline Total consumption per capita & $1,570.11$ & $1,699.01$ & $1,775.25$ & $1,589.25$ & $1,736.62$ & 0.20 & 0.79 & 0.79 & 0.26 \\
\hline Total assets & $22,296.28$ & $22,022.53$ & $25,111.19$ & $24,878.21$ & $27,749.86$ & 0.05 & 0.04 & 0.40 & 0.34 \\
\hline Loans & $9,587.59$ & $12,715.09$ & $11,210.65$ & $12,689.72$ & $11,396.99$ & 0.19 & 0.36 & 0.90 & 0.41 \\
\hline Net assets & $12,708.69$ & $9,307.43$ & $13,900.55$ & $12,188.49$ & $16,352.88$ & 0.18 & 0.01 & 0.43 & 0.15 \\
\hline Household total labor income & $4,983.38$ & $4,947.20$ & $5,350.05$ & $5,153.20$ & $5,339.18$ & 0.27 & 0.22 & 0.97 & 0.57 \\
\hline Household private transfers & 490.83 & 661.29 & 601.76 & 679.28 & 557.73 & 0.63 & 0.51 & 0.77 & 0.43 \\
\hline Household public transfers & 16.04 & 16.35 & 20.74 & 11.83 & 16.39 & 0.96 & 0.99 & 0.57 & 0.49 \\
\hline Household net income & $5,490.24$ & $5,624.83$ & $5,972.55$ & $5,844.31$ & $5,913.30$ & 0.13 & 0.29 & 0.84 & 0.82 \\
\hline
\end{tabular}


Table A3: Impact of treatment on household diet indicators

\begin{tabular}{|c|c|c|c|c|c|}
\hline & & $\begin{array}{l}\text { Per capita daily } \\
\text { caloric intake }\end{array}$ & Food poverty & $\begin{array}{l}\text { Food consumption } \\
\text { score }(\text { FCS })\end{array}$ & $\begin{array}{l}\text { Low FCS } \\
(\mathrm{FCS}<35)\end{array}$ \\
\hline \multirow[t]{13}{*}{ North } & Cash & $\begin{array}{c}74.78 \\
(29.18)^{* *}\end{array}$ & $\begin{array}{l}-0.05 \\
(0.03)\end{array}$ & $\begin{array}{c}6.84 \\
(1.12)^{* * *}\end{array}$ & $\begin{array}{c}-0.17 \\
(0.03)^{* * *}\end{array}$ \\
\hline & Food & $\begin{array}{c}142.27 \\
(30.73)^{* * *}\end{array}$ & $\begin{array}{c}-0.10 \\
(0.03)^{* * *}\end{array}$ & $\begin{array}{c}9.06 \\
(1.09)^{* * *}\end{array}$ & $\begin{array}{c}-0.21 \\
(0.03)^{* * *}\end{array}$ \\
\hline & Cash and food & $\begin{array}{c}79.94 \\
(30.20)^{* * *}\end{array}$ & $\begin{array}{l}-0.04 \\
(0.03)\end{array}$ & $\begin{array}{c}6.79 \\
(1.17)^{* * *}\end{array}$ & $\begin{array}{c}-0.17 \\
(0.03)^{* * *}\end{array}$ \\
\hline & Cash $+\mathrm{BCC}$ & $\begin{array}{c}278.47 \\
(34.56)^{* * *}\end{array}$ & $\begin{array}{c}-0.26 \\
(0.04)^{* * *}\end{array}$ & $\begin{array}{c}23.61 \\
(1.35)^{* * *}\end{array}$ & $\begin{array}{c}-0.25 \\
(0.03)^{* * *}\end{array}$ \\
\hline & $R^{2}$ & 0.08 & 0.05 & 0.25 & 0.09 \\
\hline & $N$ & 2,395 & 2,395 & 2,395 & 2,395 \\
\hline & Mean of Control & 1827.86 & 0.80 & 45.43 & 0.26 \\
\hline & P-value: $\mathrm{Cash}=\mathrm{Cash}+\mathrm{BCC}$ & 0.00 & 0.00 & 0.00 & 0.00 \\
\hline & P-value: Food $=$ Cash + BCC & 0.00 & 0.00 & 0.00 & 0.00 \\
\hline & P-value: Cash\&food $=\mathrm{Cash}+\mathrm{BCC}$ & 0.00 & 0.00 & 0.00 & 0.00 \\
\hline & P-value: $\mathrm{Cash}=\mathrm{Cash}$ and food & 0.85 & 0.88 & 0.96 & 0.85 \\
\hline & P-value: Food $=$ Cash and food & 0.03 & 0.10 & 0.04 & 0.04 \\
\hline & P-value: Cash $=$ Food & 0.02 & 0.14 & 0.04 & 0.03 \\
\hline \multirow[t]{13}{*}{ South } & Cash & $\begin{array}{c}27.65 \\
(33.31)\end{array}$ & $\begin{array}{l}-0.04 \\
(0.04)\end{array}$ & $\begin{array}{c}2.62 \\
(1.04)^{* *}\end{array}$ & $\begin{array}{l}-0.02 \\
(0.01)\end{array}$ \\
\hline & Food & $\begin{array}{c}8.81 \\
(33.81)\end{array}$ & $\begin{array}{l}-0.02 \\
(0.04)\end{array}$ & $\begin{array}{c}4.84 \\
(1.10)^{* * *}\end{array}$ & $\begin{array}{c}-0.04 \\
(0.01)^{* * *}\end{array}$ \\
\hline & Cash and food & $\begin{array}{c}38.63 \\
(36.08)\end{array}$ & $\begin{array}{l}-0.05 \\
(0.03)\end{array}$ & $\begin{array}{c}5.20 \\
(1.28)^{* * *}\end{array}$ & $\begin{array}{l}-0.02 \\
(0.01)\end{array}$ \\
\hline & Food + BCC & $\begin{array}{c}139.11 \\
(39.77)^{* * *}\end{array}$ & $\begin{array}{c}-0.15 \\
(0.04)^{* * *}\end{array}$ & $\begin{array}{c}12.57 \\
(1.25)^{* * *}\end{array}$ & $\begin{array}{c}-0.05 \\
(0.01)^{* * *}\end{array}$ \\
\hline & $R^{2}$ & 0.05 & 0.03 & 0.14 & 0.02 \\
\hline & $N$ & 2,425 & 2,425 & 2,425 & 2,425 \\
\hline & Mean of Control & 1932.73 & 0.74 & 54.29 & 0.06 \\
\hline & P-value: Cash $=$ Food + BCC & 0.01 & 0.01 & 0.00 & 0.00 \\
\hline & P-value: Food $=$ Food + BCC & 0.00 & 0.00 & 0.00 & 0.18 \\
\hline & P-value: Cash\&food=Food + BCC & 0.02 & 0.01 & 0.00 & 0.00 \\
\hline & P-value: $\mathrm{Cash}=\mathrm{Cash}$ and food & 0.77 & 0.82 & 0.03 & 0.59 \\
\hline & P-value: Food $=$ Cash and food & 0.43 & 0.54 & 0.77 & 0.15 \\
\hline & P-value: Cash $=$ Food & 0.59 & 0.73 & 0.02 & 0.06 \\
\hline
\end{tabular}

Standard errors clustered at the village level. ${ }^{*} p<0.1 ; * * p<0.05 ; * * * p<0.01$. 
Table A4: Impact of treatment on household members' monthly labor income (in baseline Tk, based on last 7 days)

\begin{tabular}{|c|c|c|c|c|}
\hline & & Adult male labor income & Adult female labor income & Child under 18 labor income \\
\hline \multirow[t]{13}{*}{ North } & "Cash & $\begin{array}{c}202.14 \\
(203.49)\end{array}$ & $\begin{array}{l}-30.39 \\
(65.87)\end{array}$ & $\begin{array}{c}40.12 \\
(40.25)\end{array}$ \\
\hline & Food & $\begin{array}{c}142.88 \\
(197.46)\end{array}$ & $\begin{array}{c}36.38 \\
(62.20)\end{array}$ & $\begin{array}{c}12.50 \\
(27.43)\end{array}$ \\
\hline & Cash and food & $\begin{array}{c}24.97 \\
(184.34)\end{array}$ & $\begin{array}{c}27.54 \\
(54.84)\end{array}$ & $\begin{array}{c}13.89 \\
(32.54)\end{array}$ \\
\hline & Cash + BCC & $\begin{array}{c}435.62 \\
(212.81)^{* *}\end{array}$ & $\begin{array}{c}2.45 \\
(52.18)\end{array}$ & $\begin{array}{c}16.55 \\
(31.64)\end{array}$ \\
\hline & $R^{2}$ & 0.07 & 0.04 & 0.06 \\
\hline & $N$ & 2,395 & 2,395 & 2,395 \\
\hline & Mean of Control & 3677.40 & 375.37 & 50.26 \\
\hline & P-value: $\mathrm{Cash}=\mathrm{Cash}+\mathrm{BCC}$ & 0.31 & 0.58 & 0.60 \\
\hline & P-value: Food $=$ Cash $+B C C$ & 0.19 & 0.54 & 0.90 \\
\hline & P-value: Cash and food $=\mathrm{Cash}+\mathrm{BCC}$ & 0.05 & 0.59 & 0.94 \\
\hline & P-value: $\mathrm{Cash}=\mathrm{Cash}$ and food & 0.38 & 0.35 & 0.56 \\
\hline & P-value: Food $=$ Cash and food & 0.55 & 0.88 & 0.97 \\
\hline & P-value: Cash $=$ Food & 0.78 & 0.33 & 0.50 \\
\hline \multirow[t]{13}{*}{ South } & Cash & $\begin{array}{c}488.74 \\
(207.17)^{* *}\end{array}$ & $\begin{array}{l}-18.90 \\
(62.67)\end{array}$ & $\begin{array}{c}29.86 \\
(47.11)\end{array}$ \\
\hline & Food & $\begin{array}{c}129.94 \\
(208.67)\end{array}$ & $\begin{array}{l}-40.20 \\
(63.29)\end{array}$ & $\begin{array}{l}-27.73 \\
(38.79)\end{array}$ \\
\hline & Cash and food & $\begin{array}{c}74.40 \\
(242.05)\end{array}$ & $\begin{array}{l}104.66 \\
(76.82)\end{array}$ & $\begin{array}{l}-39.07 \\
(41.35)\end{array}$ \\
\hline & Food + BCC & $\begin{array}{c}579.57 \\
(213.84)^{* * *}\end{array}$ & $\begin{array}{c}57.45 \\
(63.73)\end{array}$ & $\begin{array}{l}-46.27 \\
(38.44)\end{array}$ \\
\hline & $R^{2}$ & 0.17 & 0.02 & 0.07 \\
\hline & $N$ & 2,425 & 2,425 & 2,425 \\
\hline & Mean of Control & 4432.28 & 400.86 & 132.29 \\
\hline & P-value: Cash $=$ Food + BCC & 0.69 & 0.20 & 0.07 \\
\hline & P-value: Food $=$ Food + BCC & 0.05 & 0.10 & 0.55 \\
\hline & P-value: Cash and food $=$ Food + BCC & 0.05 & 0.52 & 0.83 \\
\hline & P-value: $\mathrm{Cash}=\mathrm{Cash}$ and food & 0.10 & 0.09 & 0.11 \\
\hline & P-value: Food $=$ Cash and food & 0.83 & 0.05 & 0.74 \\
\hline & P-value: Cash $=$ Food & 0.10 & 0.72 & 0.16 \\
\hline
\end{tabular}

Standard errors clustered at the village level. * $p<0.1 ; * *<<0.05 ; * * p<0.01$. 
Table A5: Impact of treatment on adult male monthly labor income (in baseline Tk, based on last 7 days)

\begin{tabular}{|c|c|c|c|c|c|c|}
\hline & & $\begin{array}{l}\text { Male total labor } \\
\text { income }\end{array}$ & $\begin{array}{l}\text { Male agricultural } \\
\text { wage income }\end{array}$ & $\begin{array}{l}\text { Male non-agricultural } \\
\text { wage income }\end{array}$ & $\begin{array}{c}\text { Male own } \\
\text { farm income }\end{array}$ & $\begin{array}{l}\text { Male non-farm } \\
\text { self-employment } \\
\text { income }\end{array}$ \\
\hline \multirow[t]{13}{*}{ North } & Cash & $\begin{array}{l}202.14 \\
(203.49)\end{array}$ & $\begin{array}{l}-230.38 \\
(152.96)\end{array}$ & $\begin{array}{c}103.36 \\
(126.95)\end{array}$ & $\begin{array}{l}132.59 \\
(98.19)\end{array}$ & $\begin{array}{l}222.16 \\
(135.06)\end{array}$ \\
\hline & Food & $\begin{array}{c}142.88 \\
(197.46)\end{array}$ & $\begin{array}{c}-300.99 \\
(150.53)^{* *}\end{array}$ & $\begin{array}{c}237.97 \\
(122.48)^{*}\end{array}$ & $\begin{array}{c}101.35 \\
(100.38)\end{array}$ & $\begin{array}{c}133.84 \\
(143.59)\end{array}$ \\
\hline & Cash and food & $\begin{array}{c}24.97 \\
(184.34)\end{array}$ & $\begin{array}{l}-173.01 \\
(160.62)\end{array}$ & $\begin{array}{c}18.32 \\
(121.88)\end{array}$ & $\begin{array}{l}112.68 \\
(95.55)\end{array}$ & $\begin{array}{c}88.64 \\
(130.50)\end{array}$ \\
\hline & Cash + BCC & $\begin{array}{c}435.62 \\
(212.81)^{* *}\end{array}$ & $\begin{array}{l}-257.59 \\
(161.35)\end{array}$ & $\begin{array}{c}40.15 \\
(120.01)\end{array}$ & $\begin{array}{c}299.05 \\
(112.70)^{* * *}\end{array}$ & $\begin{array}{c}378.43 \\
(156.88)^{* *}\end{array}$ \\
\hline & $R^{2}$ & 0.07 & 0.09 & 0.06 & 0.11 & 0.19 \\
\hline & $N$ & 2,395 & 2,395 & 2,395 & 2,395 & 2,395 \\
\hline & Mean of Control & 3677.40 & 1165.89 & 603.63 & 627.59 & 1280.30 \\
\hline & P-value: $\mathrm{Cash}=\mathrm{Cash}+\mathrm{BCC}$ & 0.31 & 0.84 & 0.64 & 0.15 & 0.31 \\
\hline & P-value: Food $=$ Cash $+B C C$ & 0.19 & 0.75 & 0.13 & 0.09 & 0.13 \\
\hline & P-value: Cash\&food $=$ Cash $+B C C$ & 0.05 & 0.56 & 0.87 & 0.10 & 0.05 \\
\hline & P-value: $\mathrm{Cash}=\mathrm{Cash}$ and food & 0.38 & 0.67 & 0.53 & 0.84 & 0.30 \\
\hline & P-value: Food $=$ Cash and food & 0.55 & 0.33 & 0.10 & 0.91 & 0.74 \\
\hline & P-value: Cash $=$ Food & 0.78 & 0.57 & 0.33 & 0.76 & 0.53 \\
\hline \multirow[t]{13}{*}{ South } & Cash & $\begin{array}{c}488.74 \\
(207.17)^{* *}\end{array}$ & $\begin{array}{c}282.06 \\
(134.58)^{* *}\end{array}$ & $\begin{array}{c}-63.68 \\
(171.75)\end{array}$ & $\begin{array}{c}-0.80 \\
(145.85)\end{array}$ & $\begin{array}{c}126.42 \\
(183.27)\end{array}$ \\
\hline & Food & $\begin{array}{c}129.94 \\
(208.67)\end{array}$ & $\begin{array}{c}49.28 \\
(108.40)\end{array}$ & $\begin{array}{c}-33.73 \\
(185.31)\end{array}$ & $\begin{array}{c}54.47 \\
(159.84)\end{array}$ & $\begin{array}{l}-53.01 \\
(163.03)\end{array}$ \\
\hline & Cash and food & $\begin{array}{c}74.40 \\
(242.05)\end{array}$ & $\begin{array}{c}-12.35 \\
(108.29)\end{array}$ & $\begin{array}{l}-57.11 \\
(185.07)\end{array}$ & $\begin{array}{c}-57.44 \\
(147.50)\end{array}$ & $\begin{array}{c}73.11 \\
(174.80)\end{array}$ \\
\hline & Food + BCC & $\begin{array}{c}579.57 \\
(213.84)^{* * *}\end{array}$ & $\begin{array}{c}165.73 \\
(125.21)\end{array}$ & $\begin{array}{c}19.50 \\
(189.15)\end{array}$ & $\begin{array}{c}172.39 \\
(150.14)\end{array}$ & $\begin{array}{c}128.50 \\
(156.46)\end{array}$ \\
\hline & $R^{2}$ & 0.17 & 0.05 & 0.08 & 0.23 & 0.26 \\
\hline & $N$ & 2,425 & 2,425 & 2,425 & 2,425 & 2,425 \\
\hline & Mean of Control & 4432.28 & 545.36 & 1387.72 & 1093.12 & 1406.08 \\
\hline & P-value: Cash $=$ Food + BCC & 0.69 & 0.43 & 0.61 & 0.20 & 0.99 \\
\hline & P-value: Food $=$ Food + BCC & 0.05 & 0.36 & 0.77 & 0.43 & 0.30 \\
\hline & P-value: Cash\&food $=$ Food + BCC & 0.05 & 0.16 & 0.67 & 0.09 & 0.77 \\
\hline & P-value: $\mathrm{Cash}=\mathrm{Cash}$ and food & 0.10 & 0.03 & 0.97 & 0.67 & 0.79 \\
\hline & P-value: Food $=$ Cash and food & 0.83 & 0.58 & 0.89 & 0.44 & 0.50 \\
\hline & P-value: Cash $=$ Food & 0.10 & 0.09 & 0.85 & 0.70 & 0.35 \\
\hline
\end{tabular}

Standard errors clustered at the village level. $* p<0.1 ; * * p<0.05 ; * * * p<0.01$ 
Table A6: Impact of treatment on adult female monthly labor income (in baseline Tk, based on last 7 days)

\begin{tabular}{|c|c|c|c|c|c|c|}
\hline & & $\begin{array}{l}\text { Female total labor } \\
\text { income }\end{array}$ & $\begin{array}{c}\text { Female agricultural } \\
\text { wage income }\end{array}$ & $\begin{array}{l}\text { Female non-agricultural } \\
\text { wage income }\end{array}$ & $\begin{array}{l}\text { Female own } \\
\text { farm labor } \\
\text { income }\end{array}$ & $\begin{array}{l}\text { Female non-farm } \\
\text { self-employment } \\
\text { income }\end{array}$ \\
\hline \multirow[t]{13}{*}{ North } & Cash & $\begin{array}{l}-30.39 \\
(65.87)\end{array}$ & $\begin{array}{l}-61.92 \\
(40.78)\end{array}$ & $\begin{array}{c}-58.36 \\
(28.82)^{* *}\end{array}$ & $\begin{array}{c}70.65 \\
(34.69)^{* *}\end{array}$ & $\begin{array}{c}21.23 \\
(17.49)\end{array}$ \\
\hline & Food & $\begin{array}{c}36.38 \\
(62.20)\end{array}$ & $\begin{array}{l}-49.82 \\
(36.25)\end{array}$ & $\begin{array}{c}-2.57 \\
(34.22)\end{array}$ & $\begin{array}{c}69.98 \\
(22.67)^{* * *}\end{array}$ & $\begin{array}{c}22.38 \\
(25.95)\end{array}$ \\
\hline & Cash and food & $\begin{array}{c}27.54 \\
(54.84)\end{array}$ & $\begin{array}{l}-57.35 \\
(36.31)\end{array}$ & $\begin{array}{l}-25.42 \\
(31.11)\end{array}$ & $\begin{array}{c}75.30 \\
(25.18)^{* * *}\end{array}$ & $\begin{array}{c}35.20 \\
(22.80)\end{array}$ \\
\hline & Cash + BCC & $\begin{array}{c}2.45 \\
(52.18) \\
\end{array}$ & $\begin{array}{c}-64.82 \\
(36.76)^{*} \\
\end{array}$ & $\begin{array}{c}-63.09 \\
(27.59)^{* *} \\
\end{array}$ & $\begin{array}{c}130.64 \\
(26.46)^{* * *} \\
\end{array}$ & $\begin{array}{c}4.27 \\
(17.40) \\
\end{array}$ \\
\hline & $R^{2}$ & 0.04 & 0.06 & 0.04 & 0.01 & 0.01 \\
\hline & $N$ & 2,395 & 2,395 & 2,395 & 2,395 & 2,395 \\
\hline & Mean of Control & 375.37 & 147.12 & 93.91 & 100.54 & 33.80 \\
\hline & P-value: $\mathrm{Cash}=\mathrm{Cash}+\mathrm{BCC}$ & 0.58 & 0.93 & 0.80 & 0.13 & 0.31 \\
\hline & P-value: Food $=$ Cash + BCC & 0.54 & 0.58 & 0.02 & 0.04 & 0.47 \\
\hline & P-value: Cash\&food $=\mathrm{Cash}+\mathrm{BCC}$ & 0.59 & 0.78 & 0.10 & 0.08 & 0.17 \\
\hline & P-value: $\mathrm{Cash}=\mathrm{Cash}$ and food & 0.35 & 0.89 & 0.17 & 0.90 & 0.54 \\
\hline & P-value: Food=Cash and food & 0.88 & 0.78 & 0.45 & 0.85 & 0.66 \\
\hline & P-value: Cash=Food & 0.33 & 0.70 & 0.05 & 0.99 & 0.96 \\
\hline \multirow[t]{13}{*}{ South } & Cash & $\begin{array}{l}-18.90 \\
(62.67)\end{array}$ & $\begin{array}{c}18.81 \\
(20.39)\end{array}$ & $\begin{array}{l}-33.60 \\
(40.12)\end{array}$ & $\begin{array}{c}10.02 \\
(30.57)\end{array}$ & $\begin{array}{l}-14.06 \\
(14.09)\end{array}$ \\
\hline & Food & $\begin{array}{l}-40.20 \\
(63.29)\end{array}$ & $\begin{array}{c}10.15 \\
(18.85)\end{array}$ & $\begin{array}{l}-15.20 \\
(44.21)\end{array}$ & $\begin{array}{l}-48.49 \\
(32.40)\end{array}$ & $\begin{array}{c}13.61 \\
(18.19)\end{array}$ \\
\hline & Cash and food & $\begin{array}{l}104.66 \\
(76.82)\end{array}$ & $\begin{array}{c}8.37 \\
(18.99)\end{array}$ & $\begin{array}{c}37.19 \\
(49.69)\end{array}$ & $\begin{array}{c}55.97 \\
(56.10)\end{array}$ & $\begin{array}{c}2.99 \\
(17.44)\end{array}$ \\
\hline & Food + BCC & $\begin{array}{r}57.45 \\
(63.73) \\
\end{array}$ & $\begin{array}{c}3.28 \\
(18.32) \\
\end{array}$ & $\begin{array}{c}6.07 \\
(47.22) \\
\end{array}$ & $\begin{array}{r}38.03 \\
(32.98) \\
\end{array}$ & $\begin{array}{r}9.94 \\
(17.38) \\
\end{array}$ \\
\hline & $R^{2}$ & 0.02 & 0.03 & 0.02 & 0.01 & 0.06 \\
\hline & $N$ & 2,425 & 2,425 & 2,425 & 2,425 & 2,425 \\
\hline & Mean of Control & 400.86 & 21.64 & 119.69 & 229.92 & 29.61 \\
\hline & P-value: $\mathrm{Cash}=$ Food $+\mathrm{BCC}$ & 0.20 & 0.50 & 0.34 & 0.31 & 0.13 \\
\hline & P-value: Food=Food + BCC & 0.10 & 0.75 & 0.64 & 0.00 & 0.85 \\
\hline & P-value: Cash\&food=Food + BCC & 0.52 & 0.82 & 0.54 & 0.74 & 0.72 \\
\hline & P-value: $\mathrm{Cash}=\mathrm{Cash}$ and food & 0.09 & 0.66 & 0.11 & 0.39 & 0.29 \\
\hline & P-value: Food=Cash and food & 0.05 & 0.94 & 0.27 & 0.05 & 0.59 \\
\hline & P-value: Cash=Food & 0.72 & 0.72 & 0.63 & 0.03 & 0.10 \\
\hline
\end{tabular}

Standard errors clustered at the village level. * $p<0.1 ; * * p<0.05 ; * * * p<0.01$. 


\section{ALL IFPRI DISCUSSION PAPERS}

All discussion papers are available here

They can be downloaded free of charge

INTERNATIONAL FOOD POLICY RESEARCH INSTITUTE

www.ifpri.org

\section{IFPRI HEADQUARTERS}

1201 Eye Street, NW

Washington, DC 20005 USA

Tel.: +1-202-862-5600

Fax: +1-202-862-5606

Email: ifpri@cgiar.org 